\title{
A Review on Preferential Oxidation of Carbon Monoxide in Hydrogen Rich Gases
}

\author{
A. Mishra, and R. Prasad * \\ Department of Chemical Engineering \& Technology, Banaras Hindu University, Varanasi 221005, India
}

Received: 22nd October 2010, Revised: 12nd January 2011, Accepted: 19th January 2011

\begin{abstract}
In this review, recent works on the preferential oxidation of carbon monoxide in hydrogen rich gases for fuel cell applications are summarized. $\mathrm{H}_{2}$ is used as a fuel for polymer-electrolyte membrane fuel cell (PEMFC). It is produced by reforming of natural gas or liquid fuels followed by water gas shift reaction. The produced gas consists of $\mathrm{H}_{2}, \mathrm{CO}$, and $\mathrm{CO}_{2}$. In which $\mathrm{CO}$ content is around $1 \%$, which is highly poisonous for the Pt anode of the PEMFC so that further removal of $\mathrm{CO}$ is needed. Catalytic preferential oxidation of $\mathrm{CO}$ (CO-PROX) is one of the most suitable methods of purification of $\mathrm{H}_{2}$ because of high $\mathrm{CO}$ conversion rate at low temperature range, which is preferable for PEMFC operating conditions. Catalysts used for COPROX are mainly noble metal based; gold based and base metal oxide catalysts among them Copper-Ceria based catalysts are the most appropriate due to its low cost, easy availability and result obtained by these catalysts are comparable with the conventional noble metal catalysts. Copyright (C) 2011 by BCREC UNDIP. All rights reserved.
\end{abstract}

Keywords: Hydrogen purification, CO-PROX, PEMFC, Methods for CO-removal, Catalysts for CO- PROX

\section{Introduction}

Fuel cells convert chemical energy directly into electrical energy with high efficiency and practically zero emission of pollutants. Fuel cell technology has a number of applications, such as micro/ portable power, stationary power for buildings and distributed generation for remote areas. Prototype vehicles adopting fuel cells in an effort to reduce atmospheric pollution are becoming very popular [1-3]. Fuel cells come in many varieties; however, they all work in the same general manner [4]. A variety of fuel cells for different applications is under development [5-7]: solid polymer fuel cells (SPFC), also known as proton-exchange membrane fuel cells (PEMFC) operating at $80{ }^{\circ} \mathrm{C}$, alkaline fuel cells (AFC), operating at $100{ }^{\circ} \mathrm{C}$, phosphoric acid fuel cells
(PAFC) for $200{ }^{\circ} \mathrm{C}$ operation, molten carbonate fuel cells (MCFC) at $650{ }^{\circ} \mathrm{C}$, solid oxide fuel cells (SOFC) for high temperature operation, 800-1100 ${ }^{\mathrm{O}} \mathrm{C}$.

PEMFC have attracted significant interest due to their low temperature of operation $\left(80^{\circ} \mathrm{C}\right)$, high power density, high efficiency and the environmentally benign nature of their exhaust. PEMFC promises to be clean and efficient alternative to combustion of fuels for power generation in stationary and mobile applications [8]. The PEMFC's ideal fuel is hydrogen; it can be produced through steam reforming, partial oxidation or auto-thermal reforming of liquid fuels or natural gas in combination with the water gas shift reaction. Hydrogen could likely be generated

\footnotetext{
* Corresponding Author, E-mail: rprasad.che@itbhu.ac.in (R. Prasad)

Tel.: +91542 2367323, fax: +915422368092.
} 
on-board using a reformer, together with significant amounts of $\mathrm{CO}$ and $\mathrm{CO}_{2}$. A subsequent water-gas-shift (WGS) reaction reduces the amount of $\mathrm{CO}$ to $1 \%$ [9]. The anode catalysts of PEMFC which are operated at relatively low temperatures $\left(80-120{ }^{0} \mathrm{C}\right)$ have been demonstrated to be easily poisoned by traces of $\mathrm{CO}$ (even around 1ppm) in the hydrogen rich feed gas. Therefore it is necessary to eliminate the traces of $\mathrm{CO}$ in the hydrogen stream with a minimum hydrogen loss [10].

Several different methods for $\mathrm{CO}$ removal from the hydrogen stream have been reported [1]. The main methods are as follows: i) Purification with hydrogen selective membrane, ii) $\mathrm{CO}$ methanation, iii) Pressure swing adsorption, and iv) Preferential oxidation (PROX) of CO. For the application of small-scale fuel processor, the selective membrane purification, CO methanation, and the CO-PROX have been considered to be promising. Many research projects sanctioned [8, 87, 92, 94-100], several Ph.D. theses approved [11-14], a number of patents granted [15-21] and numerous studies have been conducted on preferential oxidation of $\mathrm{CO}$ in $\mathrm{H}_{2}$ rich gases. Ghenciu [3] reviewed fuel processing catalysts for hydrogen production in PEM fuel cell systems, emphasising WGS reaction. Park et al. [4] reviewed progress in selective $\mathrm{CO}$ removal in a $\mathrm{H}_{2}$-rich stream. This brief article is an attempt to summarise the recent progress on main methods of $\mathrm{CO}$ removal in brief and detailed of preferential oxidation of CO. This review paper will be beneficial to the application of fuel cells as well as chemical, petrochemical industries and refineries utilizing very pure hydrogen.

\subsection{Purification with hydrogen selective membrane}

One alternative to purify hydrogen is the use of hydrogen selective membranes due to their easy preparation, low energy consumption and cost effectiveness at low gas volumes [22, 23]. There are several kinds of membranes which can be organized into three categories: (i) polymeric, (ii) metallic and (iii) inorganic membranes like zeolite membranes. Polymer membranes have several advantages like having a low cost and not causing significant pressure drops. However, mechanical strength problems and high sensitivity to swelling and compacting reduce their usefulness for this purpose $[24,25]$. The second type, metallic membranes, has an excellent hydrogen permeance but suffer from hydrogen embrittlement at low temperatures

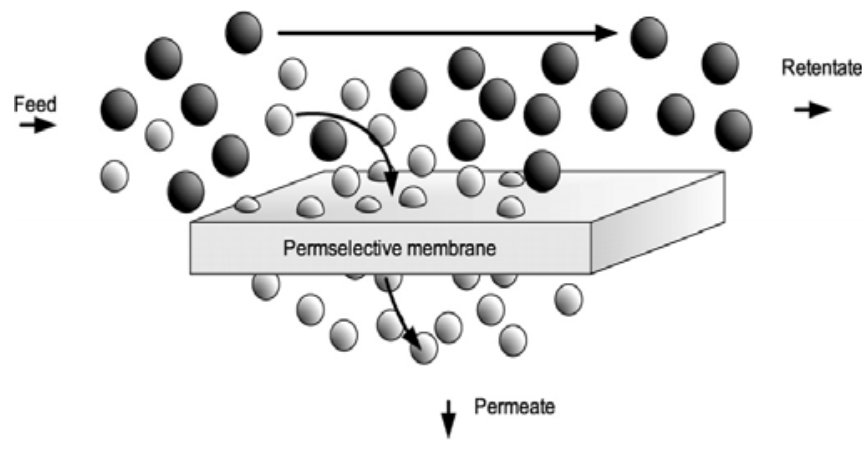

Figure 1. Simplified concept schematic of membrane separation

[26]. This is eliminated by using alloys but the product is more expensive. The latter, zeolite membranes, combine the general advantages of inorganic membranes like temperature stability and solvent resistance with those of polymeric membranes as they are composed of a thin homogeneous layer.

Fig. 1 shows a schematic of the semipermeable membrane separation process, in which the driving force is often pressure or concentration gradient across the membrane. Hydrogen separations from highly supercritical gases, such as methane, carbon monoxide, and nitrogen are easy to achieve by polymeric membranes, because of the extremely high diffusion coefficient of hydrogen relative to all other molecules except helium.

To meet the requirements of PEMFC feed such as a high perm-selectivity for $\mathrm{H}_{2}$ and a high $\mathrm{H}_{2}$ permeability, the dense phase metal membrane in which the solution diffusion is dominant has been considered to be most plausible [27]. Sotowa et al. [28] compared the Pt-loaded Y-type zeolite membrane (PtY membrane) and a Rh-loaded Y$\mathrm{Al}_{2} \mathrm{O}_{3}$ membrane and found that in $\mathrm{PtY}$ membrane the $\mathrm{H}_{2}$ permeance is very high because of the large zeolitic pores. The permeation selectivity for $\mathrm{H}_{2}$ over other gases is of the order of 10. CO oxidation can be largely attributed to the slow diffusivity of $\mathrm{CO}$ in the pores, resulting in a long residence time of $\mathrm{CO}$ in the micro-pores. While in $\mathrm{SiO}_{2} / \mathrm{Rh} / \mathrm{Y}^{-} \mathrm{Al}_{2} \mathrm{O}_{3}$ membrane the $\mathrm{H}_{2}$ permeance is smaller than that of the $\mathrm{PtY}$ membrane, but the separation selectivity of $\mathrm{H}_{2}$ is very high. Most of the $\mathrm{CO}$ molecules are rejected at the feed side surface of the $\mathrm{H}_{2}$-selective $\mathrm{SiO}_{2}$ layer. The oxidation rate in the $\mathrm{Rh} / \mathrm{Y}-\mathrm{Al}_{2} \mathrm{O}_{3}$ layer is greatly increased because the $\mathrm{CO}$ concentration is decreased nearly to the threshold value. Bernardo et al. [29] observed that the best CO removal was obtained using a low-permeance 
zeolite catalytic membrane (Q) at low pressure. This catalytic membrane was found to be very stable with no detectable deactivation over many hours $(200 \mathrm{~h})$ of operation. In recent work, VarelaGandía et al. [30] prepared membranes by ionexchange of Na-LTA/carbon membranes, they concluded that selectivity for hydrogen purification was very high but further efforts need to be undertaken in order to improve the flux through the composite membrane materials.

\subsection{CO Methanation}

CO methanation is another method for the purification of hydrogen gas mixture. The following reactions (1-2) can be carried out over the hydrogenation catalyst in the presence of $\mathrm{CO}, \mathrm{CO}_{2}$, and $\mathrm{H}_{2}$ which are main gaseous components in the exit of water-gas shift reactor.

$$
\begin{aligned}
& \mathrm{CO}(\mathrm{g})+3 \mathrm{H}_{2}(\mathrm{~g}) \rightarrow \mathrm{CH}_{4}(\mathrm{~g})+\mathrm{H}_{2} \mathrm{O}(\mathrm{g}) \\
& \Delta \mathrm{H}^{0}{ }_{298}=-205.813 \mathrm{~kJ} / \mathrm{mol} \\
& \mathrm{CO}_{2}(\mathrm{~g})+4 \mathrm{H}_{2}(\mathrm{~g}) \rightarrow \mathrm{CH}_{4}(\mathrm{~g})+2 \mathrm{H}_{2} \mathrm{O}(\mathrm{g}) \\
& \Delta \mathrm{H}^{0}{ }_{298}=-164.647 \mathrm{~kJ} / \mathrm{mol}
\end{aligned}
$$

The selective CO Methanation (Eq. 1) can be promising because this does not require the introduction of any gases such as air in the PROX system [4]. Complete removal of $\mathrm{CO}$ by methanation in $\mathrm{H}_{2}$-rich gas stream is performed over different metal catalysts. $\mathrm{Ni} / \mathrm{ZrO}_{2}$ and $\mathrm{Ru} / \mathrm{TiO}_{2}$ were the most effective catalysts for complete removal of $\mathrm{CO}$ through the methanation. These catalysts can decrease a concentration of $\mathrm{CO}$ from
$0.5 \%$ to $20 \mathrm{ppm}$ in the gases formed by the steam reforming of methane with a significantly low conversion of $\mathrm{CO}_{2}$ into methane [31]. Dagle et al. [32] used $\mathrm{Ru}$-based catalysts and found that it was capable of reducing $\mathrm{CO}$ in a reformate to less than $100 \mathrm{ppm}$ over a wide temperature range from 240 to $280{ }^{\circ} \mathrm{C}$, while keeping hydrogen consumption below 10\%. [33-36]. CO methanation experiments showed that it is difficult to reach the goal of deep $\mathrm{CO}$ removal depth of below $10 \mathrm{ppm}$. A two-stage methanation method by applying two kinds of catalysts is proposed by $\mathrm{Li}$ et al. [37] that is, one catalyst with relatively low activity and high selectivity for the first stage at higher temperatures, and another one with relatively high activity for the second stage at lower temperatures. $\mathrm{CO}$ can be removed from $10000 \mathrm{ppm}$ to below 1000 $\mathrm{ppm}$ at the first stage and to below $10 \mathrm{ppm}$ at the second stage. Generally all catalysts used for COmethanation are noble metal based which are very costly and temperature $\left(300-340{ }^{\circ} \mathrm{C}\right)$ for the reaction was also very high. Besides that in $\mathrm{CO}$ methanation, hydrogenation of $\mathrm{CO}$ takes place in which hydrogen is consumed in large amount so popularity of this method is less than preferential oxidation of carbon monoxide [4].

\subsection{Pressure swing adsorption}

The current technology used to purify hydrogen from synthesis gas is pressure swing adsorption (PSA). It is a technology used to separate some gas species from a mixture of gases under pressure according to the species molecular characteristics and affinity for an adsorbent material (activated

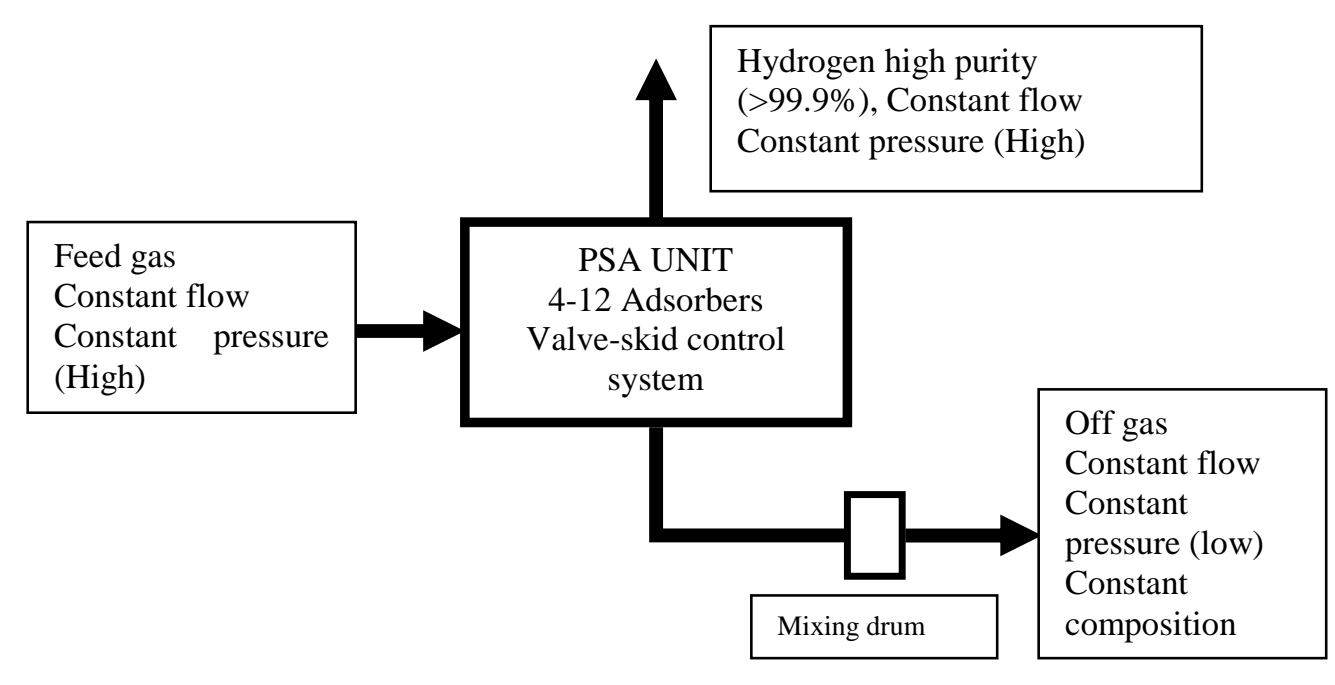

Figure 2. Pressure swing adsorption basic flow scheme 
carbon, molecular sieve 5A, silica gel, alumina, and zeolite) $[38,39]$ that preferentially adsorbs a family of related components from a mixed feed. Pressure swing adsorption processes rely on the fact that under pressure, gases tend to be attracted to solid surfaces, or "adsorbed". The higher the pressure, the more gas is adsorbed; when the pressure is reduced, the gas is released, or desorbed. PSA processes can be used to separate gases in a mixture because different gases tend to be attracted to different solid surfaces more or less strongly. Although many adsorbents are commercially available, there are still demand for robust (high chemical stability against other contaminants, high mechanical stability against attrition), cheap (low synthesis cost since adsorbent cost represents a significant part of the investment cost) and energy efficient materials [40-41]. The basic schematic flow diagram of PSA technology is shown in fig. 2.

Production of pure hydrogen from a gas mixture containing 60-90 mol\% hydrogen by using pressure swing adsorption (PSA) processes has become the state-of-the-art technology in the chemical and petrochemical industries [42]. Several hundred $\mathrm{PSA}-\mathrm{H}_{2}$ process units have been installed around the world (USA, France, Spain, Argentina, Brazil, China, etc). The two most common gas streams used for this application are (a) the steam-methane reformer off-gas after it has been further treated in a water-gas shift reactor and (b) the refinery off-gas from various sources. The typical feed gas compositions to the PSA system for these cases are (a) $70-80 \% \mathrm{H}_{2}, 15$ $25 \% \mathrm{CO}_{2}, 3-6 \% \mathrm{CH}_{4}, 1-3 \% \mathrm{CO}$, and trace $\mathrm{N}_{2}$; and (b) $65-90 \% \mathrm{H}_{2}, 3-20 \% \mathrm{CH}_{4}, 4-8 \% \mathrm{C}_{2} \mathrm{H}_{6}, 1-3 \% \mathrm{C}_{3} \mathrm{H}_{8}$, and less than $0.5 \% \mathrm{C}_{4+}$ hydrocarbons. Both feed gases are generally available at a pressure of 8 to $28 \mathrm{~atm}$ and at a temperature of 21 to $38^{\circ} \mathrm{C}$, and they are generally saturated with water. The PSA processes are designed to produce a dry hydrogenrich product stream at the feed gas pressure containing 98-99.999 mol\% $\mathrm{H}_{2}$ with a $\mathrm{H}_{2}$ recovery of 70-90\%. Yang et al. [44] Used a layered bed of activated carbon and zeolite for PSA process and reported that High purity $\mathrm{H}_{2}$ product (99.999\%) can be produced at feed gas pressure ( $8 \mathrm{~atm})$ from synthesis gas $\left(\mathrm{H}_{2}: 72.2 \%, \mathrm{CH}_{4}: 4.17 \%, \mathrm{CO}: 2.03 \%\right.$, $\left.\mathrm{CO}_{2}: 21.6 \%\right)$.

The $\mathrm{H}_{2}$ recovery increased with increasing the linear velocity and adsorption time. Majlan et al. [45] reported that Adsorption of $\mathrm{CO}$ and $\mathrm{CO}_{2}$ in mixtures of $\mathrm{H}_{2} / \mathrm{CO} / \mathrm{CO}_{2}$ was achieved using compact pressure swing adsorption (CPSA) system to produce purified hydrogen for use in fuel cell. A CPSA system was designed by combining four adsorption beds that simultaneously operate at different processes in the pressure swing adsorption (PSA) process cycle. They concluded that Activated carbon has been successfully used to adsorb CO. The adsorption capacity was $0.13 \mathrm{mmol} \mathrm{CO} / \mathrm{g}$. CPSA was able to reduce the $\mathrm{CO}$ concentration in $\mathrm{H}_{2} /$ $\mathrm{CO} / \mathrm{CO}_{2}$ mixture from $4000 \mathrm{ppm}$ to $1.4 \mathrm{ppm}$ and $\mathrm{CO}_{2}$ from $5 \%$ to $7 \mathrm{ppm}$. For the continuous adsorption but it is not suitable for non-stationary applications, due to the large dimensions and high costs of the compressor.

\subsection{Preferential oxidation of $\mathrm{CO}$}

The preferential oxidation (PROX) process is one of the most effective methods for the removal of CO trace from the reformate stream. PROX of $\mathrm{CO}$ is a reaction to convert $\mathrm{CO}$ in a $\mathrm{H}_{2}$-rich gas mixture to $\mathrm{CO}_{2}$ with minimal $\mathrm{H}_{2}$ consumption. Therefore, preferential oxidation process is an indispensable step to reduce the concentration of $\mathrm{CO}$ to $10 \mathrm{ppm}$ level in a $\mathrm{H}_{2}$ generation process [4]. The flow diagram of hydrogen purification by $\mathrm{CO}$ PROX is shown in fig. 3.

The following reactions (3-4) can occur in the PROX system.

$$
\begin{gathered}
\mathrm{CO}(\mathrm{g})+1 / 2 \mathrm{O}_{2}(\mathrm{~g}) \rightarrow \mathrm{CO}_{2}(\mathrm{~g}) \\
\Delta \mathrm{H}^{0}{ }_{298}=-282.98 \mathrm{~kJ} / \mathrm{mol} \\
\mathrm{H}_{2}(\mathrm{~g})+1 / 2 \mathrm{O}_{2}(\mathrm{~g}) \underset{\mathrm{H}_{2} \mathrm{O}(\mathrm{g})}{\Delta \mathrm{H}^{0}{ }_{298}=-241.82 \mathrm{~kJ} / \mathrm{mol}}
\end{gathered}
$$

In the first reaction (eq. 3) an excess of oxygen is provided, at around a factor of two, and about $90 \%$ of the CO is transformed. In the second step a substantially higher oxygen excess is used, at approximately a factor of 4, which is then processed with the remaining $\mathrm{CO}$, in order to reduce the $\mathrm{CO}$ concentration to less than $10 \mathrm{ppm}$ to also avoid excess CO-fraction loading, the

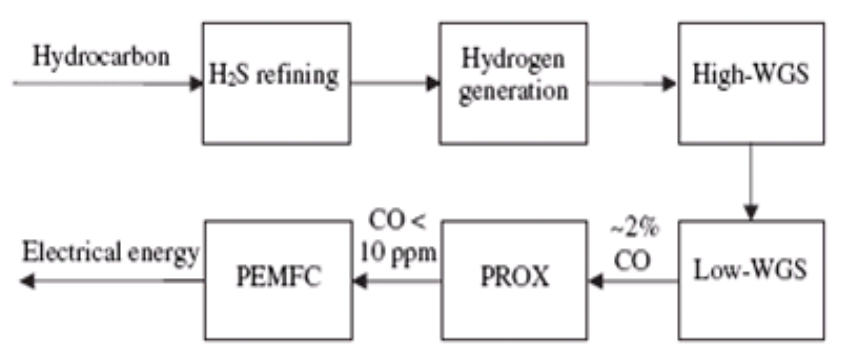

Figure 3. Flow diagram of hydrogen purification by CO-PROX 
transient operation of a $\mathrm{CO}$ adsorber may be important.

Equation (4) is highly undesirable due to the consumption of hydrogen as $100 \%$ selectivity is not possible, oxidation of $\mathrm{H}_{2}$ takes place and $\mathrm{H} 2 \mathrm{O}$ formed, which reduces the activity of prox catalyst. The disadvantage of this technology is its very strong exothermic nature, coupled with a very narrow optimal operation temperature window, and is best operated between $80{ }^{\circ} \mathrm{C}$ and $177^{\circ} \mathrm{C}$, yielding a steam loss of around one percent [36, 62, $65,80]$, Effective cooling is therefore required. In order to minimise steam generation (eqn. 2), excessive dilution with nitrogen is used. Additionally the reaction is interrupted with an intermediary cooler before proceeding to a second stage.

The instrumentation and process control complexity requirements are relatively high. The advantage of this technique over selective methanation is the higher space velocity, which reduces the required reactors size. The PROX of $\mathrm{CO}$ is a catalytic reaction where the catalyst plays a significant role in enhancing the $\mathrm{CO}$ oxidation and suppressing $\mathrm{H}_{2}$ oxidation. The key factors to achieve very low CO concentration fuel, is synthesizing a highly active, stable, and selective catalyst for PROX reaction in $\mathrm{H}_{2}$-rich gas mixture at the lower temperature range [45].

\section{Catalysts for CO-PROX}

The reported promising catalysts for CO-PROX can be grouped into three classes:

1. Supported noble metal catalysts, such as $\mathrm{Pt}, \mathrm{Pd}$, Ir, $\mathrm{Ru}$ or $\mathrm{Rh}$ [46-74],

2. Nano-gold catalysts [75-94] and

3. Base metal oxides catalysts which mainly concentrate on $\mathrm{CuO}-\mathrm{CeO}_{2}$ [8-10, 45, 95-125].

\subsection{Supported noble metal catalysts}

Many workers [46-71] studied about preferential oxidation of $\mathrm{CO}$ over noble metal based catalysts. Generally, Pt, Rh, Ru and Ir based catalysts fall in this category. The noble metal based catalysts are conventionally used for the COPROX. Hulteberg et al. [46] studied different noble metal catalysts for activity in the CO-PROX in hydrogen-rich streams and concluded that $\mathrm{Pt}$ on $\mathrm{Co}$ -oxide is a highly active catalyst for the reaction. Huang et al. [47, 48] used iridium based catalysts $\left(\mathrm{Ir} / \mathrm{CeO}_{2}\right)$ which exhibited excellent performance in PROX process. Reductive pre-treatment of $\mathrm{Ir} / \mathrm{CeO}_{2}$ was found to be beneficial to obtain higher $\mathrm{CO}$ oxidation activity at low temperatures. The presence of $1.60 \mathrm{wt} \%$ of Ir was essential for obtaining high activity in the PROX reaction. Recently, Zhang et al. [49] prepared bi-functional catalyst $\mathrm{Ir}-\mathrm{FeOx} / \mathrm{SiO}_{2}$, which was very active and selective for preferential oxidation of $\mathrm{CO}$ under $\mathrm{H}_{2}$ rich atmosphere.

Tanaka et al. [50] reported high performance in preferential oxidation of $\mathrm{CO}$ in rich hydrogen over K-promoted Rh/USY (K/Rh=3) catalysts. The concentration of $\mathrm{CO}$ was below $10 \mathrm{ppm}$ after this process. The addition of potassium to Rh/USY also promoted the activity of $\mathrm{CO}$ oxidation without hydrogen. Chin et al. [51] reported over $\mathrm{SiO}_{2}$ - and $\mathrm{Al}_{2} \mathrm{O}_{3}$-supported $\mathrm{Ru}$ Catalysts, and concluded the three major advantages over a conventional $\mathrm{Pt}$ catalyst: first lower operating temperatures, second ability to completely eliminate $\mathrm{CO}$ in a single step under realistic space velocities $(120,000$ $\mathrm{mL} / \mathrm{g} \mathrm{h})$ and $\mathrm{O}_{2}$ concentrations $\left(\mathrm{O}_{2} / \mathrm{CO}=1\right)$ without compromising the $\mathrm{CO}_{2}$ selectivity, and third wide operating temperature windows which yield $\mathrm{CO}$ outlet concentration of less than $30 \mathrm{ppm}$ even in the presence of $\mathrm{H}_{2} \mathrm{O}$ and $\mathrm{CO}_{2}\left(120-170{ }_{0} \mathrm{C}\right.$ for $\mathrm{Ru} /$ $\mathrm{SiO}_{2}$ and $180-200{ }^{\circ} \mathrm{C}$ for $\mathrm{Ru} / \mathrm{Al}_{2} \mathrm{O}_{3}$ ). Kim et al. [52] prepared various $\mathrm{Ru}$ catalysts supported on different supports such as yttria-stabilized zirconia (YSZ), $\mathrm{ZrO}_{2}, \mathrm{TiO}_{2}, \mathrm{SiO}_{2}$ and $\mathrm{Y}-\mathrm{Al}_{2} \mathrm{O}_{3}$ with a wet impregnation method. Among them, Ru/YSZ showed the highest CO conversion especially at low temperatures and it can reduce the high inlet $\mathrm{CO}$ concentration to be less than $10 \mathrm{ppm}$ even in the presence of $\mathrm{H}_{2} \mathrm{O}$ and $\mathrm{CO}_{2}$.

$\mathrm{Pt}$ and $\mathrm{Pt}$ based catalysts are the most commonly used catalysts of this category and shows better results than other noble metal catalysts. Ayastuy et al. [53] used $\mathrm{MnO}_{\mathrm{x}} / \mathrm{Pt} / \mathrm{Al}_{2} \mathrm{O}_{3}$ and reported that high $\mathrm{CO}$ conversion at high temperature range. Ceria supported $\mathrm{Pt}$ with alumina also reported high activity and selectivity for CO-PROX [54-59]. Many works [60-65] have been done over $\mathrm{Pt}-\mathrm{Fe} /$ mordenite catalysts and concluded that these catalysts gives good result even in presence of $\mathrm{H}_{2} \mathrm{O}$. Alkali metal modified catalyst increases the activity but not effect the selectivity of CO-PROX [66]. Guerrero et al. [67] studied the promotional effect of $\mathrm{Nb}$ on $\mathrm{Pt}$ supported on alumina or on niobia, for the preferential oxidation of $\mathrm{CO}$ (PROX) in hydrogen.The results show a unique effect of $\mathrm{Nb}$ as a promoter to $\mathrm{Pt}$. At low $\mathrm{Nb}$ loadings on $\mathrm{Pt} /$ alumina, the CO oxidation activity and selectivity are significantly increased. The $\mathrm{CO}$ selectivity is $100 \%$ at conversions up to about $60 \%$. Pt-Co silica or alumina aerogel catalyst exhibited excellent ability for the carbon monoxide removal but at comparatively higher temperature $[68,69]$. 
Sebastian et al. [71] studied Pt supported on different zeolitic materials (MOR, ZSM-5, FAU and ETS-10). The behaviour of the Pt-ETS-10 and PtFAU catalysts has been investigated in more depth and the results obtained have been compared and related to the different characteristics of the supports. The best results in the presence of $\mathrm{H}_{2} \mathrm{O}$ and $\mathrm{CO}_{2}$ were obtained with Pt-FAU catalysts, showing stable catalytic activity and complete conversion of $\mathrm{CO}$ at $166{ }^{\circ} \mathrm{C}$.

Luengnaruemitchai et al. [72] reported that complete $\mathrm{CO}$ conversion obtained at temperature around $200{ }^{\circ} \mathrm{C}$ over A-type zeolite-supported $\mathrm{Pt}$ catalysts; the presence of $\mathrm{H}_{2} \mathrm{O}$ depressed the activity. But bimetallic AuPt supported on zeolite catalysts have no effect of $\mathrm{H}_{2} \mathrm{O}$ or $\mathrm{CO}_{2}$ present in the reaction [72]. $\mathrm{Pt}_{3} \mathrm{Co}$ and $\mathrm{PtCu}$ intermetallic catalyst give high $\mathrm{CO}$ conversion at low temperature [73]. Recently, Consuegra et al. [74] reported that the activity and selectivity for the PROX process can be strongly enhanced by the phenomenon of electrochemical promotion. This phenomenon would allow optimizing the amount of promoter under the expected dynamic conditions of a PROX unit which is not possible with a conventional promoted heterogeneous catalyst.

\subsection{Gold based catalysts}

Gold based catalysts have high activity for the CO-PROX especially at low temperature. Luengnaruemitchai et al. [75] found that the performance of catalyst depends on the preparation method of $\mathrm{Au} / \mathrm{CeO}_{2}$ catalysts. They reported that the $\mathrm{Au} / \mathrm{CeO}_{2}$ catalyst prepared by coprecipitation method exhibited the highest activities but presence of $\mathrm{CO}_{2}$ in feed stream reduces the $\mathrm{CO}$ conversion. Wang et al. [76] used $\mathrm{Au} / \mathrm{CeO}_{2}-\mathrm{Co}_{3} \mathrm{O}_{4}$ catalysts with a $\mathrm{Ce} / \mathrm{Co}$ atomic ratio from 0.1 to 0.6 which were prepared by depositionprecipitation. CO conversion is $91 \%$ while selectivity is around $51 \%$ at temperature $80{ }^{\circ} \mathrm{C}$. Several workers [77-79] reported good results for CO-PROX on nano gold catalysts. Quinet et al. [80] studied the effect of molecular hydrogen on CO Oxidation over an unsupported silver-free gold powder and concluded that the support-free pathway for the oxidation of $\mathrm{CO}$ exists and is enhanced by the presence of hydrogen. However, even with hydrogen, our unsupported particles are found to be less efficient than the oxide-supported ones to activate oxygen, probably because of a low concentration of low-coordination active sites present at the surface of large gold particles. Au/ $\mathrm{TiO}_{2}$ catalyst possesses good catalytic activity for PROX between 25 and $50{ }^{\circ} \mathrm{C}$ and raising the reaction temperature up to $180{ }^{\circ} \mathrm{C}$ has a distinct influence on the reaction and deactivation behaviour of catalysts in the $\mathrm{CO}$ oxidation increased [81-84].

Bimetallic $\mathrm{Au}-\mathrm{Cu}$ catalysts prepared by the deposition-precipitation method for selective $\mathrm{CO}$ oxidation reaction showed that $\mathrm{Cu}$ addition increased the selectivity for CO oxidation decreasing the $\mathrm{H}_{2}$ consumption [85]. The interaction between $\mathrm{Cu}$ and $\mathrm{Au}$ seemed to be able to modify the catalytic properties of Au active sites for $\mathrm{CO}$ oxidation. Other than titania, $\mathrm{ZrO}_{2}$ supported Au catalysts obtained by direct oxidation of bulk alloy shows good results for CO-PROX at high temperature [86]. Ceria supported bimetallic catalyst [87] and rare earths-modified ceriasupported gold catalysts [88] exhibited the highest catalytic activity, selectivity, and high stability.

Manzoli et al. [89] prepared Au/doped ceria catalysts by deposition-precipitation method modified by various cations $\left(\mathrm{Sm}^{3+}, \mathrm{La}^{3+}\right.$ and $\mathrm{Zn}^{2+}$ ) The following activity order was observed: Au/Zn$\mathrm{CeO}_{2}>\mathrm{Au} / \mathrm{Sm}-\mathrm{CeO}_{2}>\mathrm{Au} / \mathrm{CeO}_{2}>\mathrm{Au} / \mathrm{La}-\mathrm{CeO}_{2}$. Catalysts showed improved tolerance towards the presence of $\mathrm{CO}_{2}$ and $\mathrm{H}_{2} \mathrm{O}$ in the PROX feed. Little amount of gold with ceria catalyst showed suppressed activity in presence of $\mathrm{CO}_{2}$ [90]. Au/iron oxide system reported less selectivity at high temperature range for $\mathrm{CO}$ oxidation [91]. Naknam et al. [92] studied over $\mathrm{Au} / \mathrm{ZnO}$ and $\mathrm{Au} / \mathrm{ZnO}-\mathrm{Fe}_{2} \mathrm{O}_{3}$ catalysts prepared by photo-deposition method under UV light, exhibited higher catalytic activity, where it achieves a complete conversion of $\mathrm{CO}$ at $30{ }^{\circ} \mathrm{C}$ and $50-73 \% \mathrm{CO}$ selectivity. The presence of a mixed oxidation state of $\mathrm{Au}$ is the active site for the PROX reaction. In recent work Laguna et al. [93] concluded that gold catalyst prepared with the $\mathrm{CeFe}_{10}$ as support is a very active for PROX reactions, especially at low temperatures compared with $\mathrm{Au} / \mathrm{CeO}_{2}$. Overall gold based catalysts are suitable only for low temperature range, same as the noble metal based catalysts.

A comparative study was investigated, in which [94] nano-structured gold catalysts supported on $\mathrm{CeO}_{2}$ and $\mathrm{MnO}_{2}$ prepared by depositionprecipitation method. The authors concluded that $\mathrm{Au} / \mathrm{CeO}_{2}$ is more active than $\mathrm{Au} / \mathrm{MnO}_{2}$ towards selective $\mathrm{CO}$ oxidation.

\subsection{Base metal oxide catalysts}

The preferential oxidation of carbon monoxide in the presence of large quantities of hydrogen was carried out over different supported base metal catalysts. The catalytic formulations [95] involved several transition metals $(\mathrm{Co}, \mathrm{Cr}, \mathrm{Cu}, \mathrm{Ni}, \mathrm{Zn})$ 
supported on oxides with different acidic, basic and redox properties $\left(\mathrm{MgO}, \mathrm{La}_{2} \mathrm{O}_{3}, \mathrm{SiO}_{2}-\mathrm{Al}_{2} \mathrm{O}_{3}, \mathrm{CeO}_{2}\right.$, $\mathrm{Ce}_{0.63} \mathrm{Zr}_{0.37} \mathrm{O}_{2}$ ). Out of them, the only ceria- and ceria-zirconia-supported copper catalysts appeared to be as active as the costly platinum group catalysts classically used for this reaction. The well -known enhancement of oxidation activity of copper, when supported on reducible oxides like $\mathrm{CeO}_{2}$, was attributed to a "synergistic" effect [96]. It is proposed that well-dispersed $\mathrm{CuO}$ on $\mathrm{CeO}_{2}$, which is reducible at a lower temperature with respect to bulk $\mathrm{CuO}$, could adsorb $\mathrm{CO}$ better. As a result, this catalyst exhibited high activity/ selectivity for low-temperature CO oxidation [97]. Easy availability and low cost make these catalysts able to replace the other noble metal and gold based catalysts [98]. The characteristics of catalysts change according to the preparation method used.

The catalytic properties are strongly affected by the synthesis procedures of the base metal catalysts. Avgouropoulos [99] reported the influence of the preparation method on the physicochemical and catalytic properties of $\mathrm{CuO}$ $\mathrm{CeO}_{2}$ catalysts for the selective $\mathrm{CO}$ oxidation in simulated reformate gas. They reported ranking order of the preparation methods of the $\mathrm{CuO}-\mathrm{CeO}_{2}$ catalyst in $\mathrm{CO}$ oxidation activity is as follows: ureanitrates combustion $>$ citrate-hydrothermal $>$ coprecipitation $>$ impregnation. Liu et al. [100] reported that $\mathrm{CuO}-\mathrm{CeO}_{2}$ catalyst prepared by chelating method has a superior catalytic performance for the preferential oxidation of $\mathrm{CO}$ in rich hydrogen, compared with the $\mathrm{CuO}-\mathrm{CeO}_{2}$ catalyst prepared by co-precipitation method. $\mathrm{Cu}$ supported ceria catalysts give very good results for CO-PROX even in presence of $\mathrm{CO}_{2}$ and $\mathrm{H}_{2} \mathrm{O}$ in feed stream and at the PEMFC operating condition [100 -107].

Different combination with $\mathrm{CuO}-\mathrm{CeO}_{2}$ as a$\mathrm{Fe}_{2} \mathrm{O}_{3}$-promoted [108], $\mathrm{KOH} / \mathrm{K}_{2} \mathrm{CO}_{3}$ on $\mathrm{CuO}-\mathrm{CeO}_{2-\mathrm{x}}$ [109], $\mathrm{CuO}-\mathrm{CeO}_{2}-\mathrm{ZrO}_{2}$ system [110,111], $\mathrm{CuO}-$ $\mathrm{CeO}_{2} / \mathrm{Al}_{2} \mathrm{O}_{3} / \mathrm{FeCrAl}$ mono-lithic catalysts [112], mesomacro-porous monolithic $\mathrm{CuO}-\mathrm{CeO}_{2} / \mathrm{a}-\mathrm{Al}_{2} \mathrm{O}_{3}$ catalysts [113], increase the activity and make copper-ceria system stable which is most important characteristic of any catalyst. $\mathrm{CuO}-\mathrm{ZnO} / \mathrm{TiO}_{2}$ catalysts were found to have interesting $\mathrm{CO}$ conversion values and resulted totally selective toward the $\mathrm{CO}$ oxidation in the technologically important 65-120 ${ }^{\circ} \mathrm{C}$ temperature range [114]. $\mathrm{CuO} / \mathrm{Ce}_{\mathrm{x}} \mathrm{Zr}_{1-\mathrm{x}} \mathrm{O}_{2} \cdot \mathrm{Al}_{2} \mathrm{O}_{3}$ catalysts exhibited much larger selectivity than, that of the noble catalyst $5 \% \mathrm{Pt} / \mathrm{Al}_{2} \mathrm{O}_{3}$ [115]. Hernández et al. [116] synthesized transition metal $(\mathrm{Cu}, \mathrm{Co}, \mathrm{Ni}$ and $\mathrm{Zn})$ modified cryptomelane-type manganese dioxide nano-materials by the milling method. All the solids were active in the preferential oxidation of $\mathrm{CO}$ in the presence of hydrogen, being the modified with copper the most active. $\mathrm{CuMn}_{2} \mathrm{O}_{4}$ nanocatalysts [117] synthesised by silica aquagel confined co-precipitation were analysed for COPROX. at moderate temperature, even at high spatial velocities.

Cobalt is another base metal which gives good results for CO-PROX reaction [118-123]. Zhao et al. [118] prepared Cobalt catalysts supported on metal oxides $\left(\mathrm{ZrO}_{2}, \mathrm{CeO}_{2}, \mathrm{SiO}_{2}, \mathrm{Al}_{2} \mathrm{O}_{3}\right.$, and $\left.\mathrm{TiO}_{2}\right)$. It was found that the $\mathrm{Co} / \mathrm{ZrO}_{2}$ catalyst had the highest $\mathrm{CO}$ oxidation activity from the series. $\mathrm{CoOx} / \mathrm{ZrO}_{2}$ catalyst was synthesized and studied for the PROX reaction under various reaction conditions and indicated that in the temperature window of interest $\left(80-200^{\circ} \mathrm{C}\right)$, this catalyst had potential for obtaining high conversions of $\mathrm{CO}$ with high $\mathrm{O}_{2}$ selectivity to $\mathrm{CO}_{2}$ [119]. $\mathrm{MnOx}$ modified $\mathrm{Co}_{3} \mathrm{O}_{4}$ $\mathrm{CeO}_{2}$ catalysts shows almost $100 \%$ conversion of $\mathrm{CO}$ present in gas mixture as $\mathrm{MnO}_{\mathrm{x}}$ into $\mathrm{Co}_{3} \mathrm{O}_{4}$ $\mathrm{CeO}_{2}$ led to more uniform mixing of $\mathrm{Co}_{3} \mathrm{O}_{4}$ and $\mathrm{CeO}_{2}$ particles and led to finely dispersed and high valence state cobalt oxides species, which contributed to high catalytic activity of $\mathrm{Co}-\mathrm{Ce}-\mathrm{Mn}$ mixed oxides catalysts [120]. $\mathrm{Co}_{3} \mathrm{O}_{4} / \mathrm{meso}^{-\mathrm{CeO}_{2}}$ catalysts with $\mathrm{Co}_{3} \mathrm{O}_{4}$ content of $10 \%$ or higher were very active and selective for preferential oxidation of $\mathrm{CO}$ in $\mathrm{H}_{2}$-rich gases. The catalysts exhibited wide temperature windows for $100 \% \mathrm{CO}$ conversion and stability is also very high. However, negative effects were observed when $\mathrm{CO}_{2}$ or $\mathrm{H}_{2} \mathrm{O}$ was added to the reaction mixture [121].

The catalytic activity and the selectivity of the $\mathrm{CO}$ oxidation of the $\mathrm{CuO}-\mathrm{CeO}_{2} / \mathrm{Y}-\mathrm{Al}_{2} \mathrm{O}_{3}$ catalyst in the selective $\mathrm{CO}$ oxidation in excess hydrogen were significantly improved by the addition of a small amount of Co. It was found that the temperature window of CO conversion $>99.9 \%$ within $210-224$ ${ }^{\circ} \mathrm{C}$ [122,123]. In recent work Woods et al. [8] prepared a highly active $\mathrm{CoO}_{\mathrm{x}} / \mathrm{CeO}_{2}$ nano-particle catalyst with high surface area $\left(78 \mathrm{~m}^{2} / \mathrm{g}\right)$. They claimed that the $10 \% \mathrm{CoO}_{\mathrm{x}} / \mathrm{CeO}_{2}$ catalyst was able to achieve near $100 \% \mathrm{CO}$ conversion under a wide range of conditions. This catalyst was stable with time-on-stream at the temperature of highest $\mathrm{CO}$ conversion. $\mathrm{H}_{2}$ concentration seems to have a negative effect on the $\mathrm{CO}$ oxidation. They observed three distinct temperatures regions of catalyst activity occur. Below $175{ }^{\circ} \mathrm{C}$ CO oxidation is dominant. Between 175 and $275{ }^{\circ} \mathrm{C}, \mathrm{CO}$ oxidation competes with $\mathrm{H}_{2}$ combustion. Above $275{ }^{\circ} \mathrm{C}$, methanation dominates. 


\section{Precious metal vs base metal catalysts}

Several authors [95, 124-126] compared the performance of base metal catalysts with precious metal catalysts for the CO-PROX. Marino et al [95] reported that ceria-zirconia-supported copper catalysts appeared to be as active as the costly platinum group catalysts classically used for this reaction. A comparative study between ceriasupported gold and copper oxide catalysts for preferential $\mathrm{CO}$ oxidation reaction was carried out by Avgouropoulos et al. [124] both catalysts were prepared by deposition-precipitation method. $\mathrm{Au} /$ ceria catalysts showed higher activity than $\mathrm{CuO} /$ ceria for the PROX reaction at temperatures lower than $120^{\circ} \mathrm{C}$, while the $\mathrm{CuO} /$ ceria catalysts were able to operate at higher temperatures, with a remarkably better selectivity. The presence of $\mathrm{CO}_{2}$ and $\mathrm{H}_{2} \mathrm{O}$ caused a significant decrease in the catalytic performance of the gold catalyst, while the $\mathrm{CuO} /$ ceria catalyst could still achieve complete removal of $\mathrm{CO}$ in the presence of $\mathrm{CO}_{2}$ and $\mathrm{H}_{2} \mathrm{O}$.

Chen et al. [125] worked on $\mathrm{Ce}_{\mathrm{x}} \mathrm{Sn}_{1-\mathrm{x}} \mathrm{O}_{2}-\mathrm{Al}_{2} \mathrm{O}_{3}$ mixed oxides catalysts prepared by the suspension/ co-precipitation method and found that its activity was comparable with, and its selectivity was much larger than, that of the noble catalyst $5 \% \mathrm{Pt} / \mathrm{Al}_{2} \mathrm{O}_{3}$.

$\mathrm{Ko}$ et al. [126] concluded that $\mathrm{Pt}-\mathrm{Ni} / \mathrm{Y}-\mathrm{Al}_{2} \mathrm{O}_{3}$ catalyst showed the highest activity and selectivity among various PROX catalysts such as metal oxides as $\mathrm{CoO}$ and $\mathrm{CuO}-\mathrm{CeO}_{2}$, supported gold catalysts as $\mathrm{Au} / \mathrm{Y}-\mathrm{Al}_{2} \mathrm{O}_{3}, \mathrm{Au} / \mathrm{CuO}, \mathrm{Au} / \mathrm{CeO}_{2} / \mathrm{Y}-\mathrm{Al}_{2} \mathrm{O}_{3}$, $\mathrm{Au} / \mathrm{CuO}-\mathrm{CeO}_{2}$ and $\mathrm{Au} / \mathrm{CeO}_{2}$, and supported $\mathrm{Pt}$ catalysts such as $\mathrm{Pt} / \mathrm{Y}-\mathrm{Al}_{2} \mathrm{O}_{3}$, and $\mathrm{Pt}-\mathrm{Co} / \mathrm{Y}-\mathrm{Al}_{2} \mathrm{O}_{3}$.

Table 2.1. Recent literature review at a glance on PROX of $\mathrm{CO}$ in $\mathrm{H}_{2}$ rich gases

\begin{tabular}{|c|c|c|c|c|}
\hline Catalyst & Preparation method & Operating parameter & Remarks & Reference \\
\hline \multicolumn{5}{|c|}{ Base metal oxide catalysts } \\
\hline $5 \% \mathrm{CuO}-\mathrm{CeO}_{2}$ & $\begin{array}{l}\text { Urea gelation/ Co- } \\
\text { precipitation }\end{array}$ & $\begin{array}{l}50 \% \mathrm{H}_{2}, 20 \% \mathrm{CO}_{2}, 0.5-1 \% \mathrm{CO} \\
10 \% \mathrm{H}_{2} \mathrm{O}-\mathrm{N}_{2}, 150-250^{\circ} \mathrm{C} \\
79980 \mathrm{ml} / \mathrm{g} \mathrm{h}\end{array}$ & $\begin{array}{l}100 \% \mathrm{CO} \text { conversion, selectivity } \approx 90 \% \text { in } \\
\text { absence of } \mathrm{CO}_{2} \& \mathrm{H}_{2} \mathrm{O} \text { presence of both it is } \\
99 \% \& 65 \% \text { at } 165^{\circ} \mathrm{C} \text { respectively. }\end{array}$ & Liu (2004) [97] \\
\hline $\begin{array}{l}7 \% \mathrm{CuO} / \mathrm{Ce}_{0.9} \\
\mathrm{Zr}_{0.1} \mathrm{O}_{2} \cdot \mathrm{Al}_{2} \mathrm{O}_{3}\end{array}$ & $\begin{array}{l}\text { Suspension/ Co- } \\
\text { precipitation }\end{array}$ & $\begin{array}{l}0.3-1 \% \mathrm{CO}, 40-75 \% \mathrm{H}_{2} 20- \\
25 \% \mathrm{CO}_{2} 155^{\circ} \mathrm{C} 10000 \mathrm{ml} / \mathrm{g} \mathrm{h}\end{array}$ & $\begin{array}{l}100 \% \text { conversion, comparable activity\& much } \\
\text { larger selectivity than that of the noble cata- } \\
\text { lyst. }\end{array}$ & Chen (2007) [115] \\
\hline $\begin{array}{l}\mathrm{MnOx} \text { modified } \mathrm{Co}_{3} \mathrm{O}_{4} \text { - } \\
\mathrm{CeO}_{2} \text {, Co: } \mathrm{Ce}: \mathrm{Mn}=8: 1: 1\end{array}$ & Co-precipitation & $\begin{array}{l}1 \% \mathrm{CO}, 1 \% \mathrm{O}_{2}, 50 \% \mathrm{H}_{2}-\mathrm{N}_{2} \\
80-180^{\circ} \mathrm{C} 40000 \mathrm{ml} / \mathrm{g} \mathrm{h}\end{array}$ & $\begin{array}{l}100 \% \text { conversion, } \mathrm{MnOx} \text { into } \mathrm{Co}_{3} \mathrm{O}_{4}-\mathrm{CeO}_{2} \\
\text { increases the interaction between } \mathrm{Co}_{3} \mathrm{O}_{4} / \mathrm{CeO}_{2} \text {, } \\
\text { selectivity } 98.2 \% \text {, at } 80^{\circ} \mathrm{C} \text {. }\end{array}$ & Guo(2008) [120] \\
\hline $\begin{array}{l}\text { Meso-porous } \mathrm{CeO}_{2} \\
\text { Supported } \mathrm{Co}_{3} \mathrm{O}_{4}, 10 \%\end{array}$ & $\begin{array}{l}\text { Surfactant- } \\
\text { templated }\end{array}$ & $\begin{array}{l}1 \% \mathrm{CO}, 1 \% \mathrm{O}_{2}, 50 \% \mathrm{H}_{2}-\mathrm{N}_{2} \\
200-300^{\circ} \mathrm{C}, 40000 \mathrm{ml} / \mathrm{g} \mathrm{h}\end{array}$ & $\begin{array}{l}100 \% \text { conversion, very active, selective and } \\
\text { stable. } \mathrm{CO}_{2} / \mathrm{H}_{2} \mathrm{O} \text { effects negatively over activ- } \\
\text { ity. }\end{array}$ & $\begin{array}{l}\text { Guo et al. (2007) } \\
{[121]}\end{array}$ \\
\hline $\mathrm{CuO}-\mathrm{CeO}_{2}$ & Chelating & $\begin{array}{l}1 \% \mathrm{CO}, 1 \text { or } 1.25 \% \mathrm{O}_{2}, 50 \% \\
\mathrm{H}_{2} \mathrm{H}_{2} \mathrm{O}, \mathrm{CO}_{2}, 120^{\circ} \mathrm{C}, 120000 \\
\mathrm{ml} / \mathrm{g} \mathrm{h}\end{array}$ & $\begin{array}{l}99.6 \% \text { conversion, superior performance to } \\
\mathrm{CuO}-\mathrm{CeO}_{2} \text { catalyst prepared by co- } \\
\text { precipitation method. }\end{array}$ & Liu (2007) [100] \\
\hline$\alpha-\mathrm{Fe}_{2} \mathrm{O}_{3}$ on $\mathrm{CuO}-\mathrm{CeO}_{2}$ & $\begin{array}{l}\text { Urea-nitrate com- } \\
\text { bustion }\end{array}$ & $\begin{array}{l}1 \% \mathrm{CO}, 1-2 \% \mathrm{O}_{2}, 40 \% \mathrm{H}_{2}, 0- \\
10 \% \mathrm{H}_{2} \mathrm{O}, 0-20 \% \mathrm{CO}_{2}, 150 \\
{ }^{0} \mathrm{C}\end{array}$ & $\begin{array}{l}100 \% \text { conversion, increasing } \mathrm{O}_{2} / \mathrm{CO} \text { ratio from } \\
1.0 \text { to } 1.5, \mathrm{CO} \text { conversion increases. } 66.5 \% \\
\text { selectivity at } 150^{\circ} \mathrm{C}\end{array}$ & $\begin{array}{l}\text { Sirichai-praert } \\
(2008)[108]\end{array}$ \\
\hline $\begin{array}{l}\mathrm{KOH} / \mathrm{K}_{2} \mathrm{CO}_{3} \text { on } \mathrm{CuO}- \\
\mathrm{CeO}_{2-x}\end{array}$ & Co-precipitation & $\begin{array}{l}1 \% \mathrm{CO}, 1.25 \% \mathrm{O}_{2}, 50 \% \mathrm{H}_{2} \\
\mathrm{H}_{2} \mathrm{O}, \mathrm{CO}_{2} .90-110{ }^{\circ} \mathrm{C} \\
30000-120000 \mathrm{ml} / \mathrm{g} \mathrm{h}\end{array}$ & $\begin{array}{l}99 \% \text { conversion, } 100 \% \text { Selectivity, particle sizes } \\
\text { decreases on } \mathrm{KOH} \text { addition, } \mathrm{CuO}-\mathrm{CeO}_{2-x} \text { cata- } \\
\text { lysts have larger surface areas }\end{array}$ & Liu (2006) [109] \\
\hline $\mathrm{CuO}-\mathrm{CeO}_{2}-\mathrm{ZrO}_{2}$ & Co-precipitation & $\begin{array}{l}74.17 \% \mathrm{H}_{2}, 0.49 \% \mathrm{CO} \\
23.26 \% \mathrm{CO}_{2} 2.08 \% \mathrm{CH}_{4} \\
177^{\circ} \mathrm{C}\end{array}$ & $\begin{array}{l}99.5 \% \text { conversion, stable, activity decreased in } \\
\text { the order } \mathrm{CuO}-\mathrm{CeO}_{2}>\mathrm{CuO}-\mathrm{CeO}_{2}-\mathrm{ZrO}_{2}>\mathrm{CuO}- \\
\mathrm{ZrO}_{2}\end{array}$ & $\begin{array}{l}\text { Ratnasamy } \\
(2004)[110]\end{array}$ \\
\hline $\begin{array}{l}\mathrm{Nd} \text { - or } \mathrm{Zr} \text {-modified } \\
\mathrm{CuO}-\mathrm{CeO}_{2} / \mathrm{Al}_{2} \mathrm{O}_{3} \\
/ \mathrm{FeCrAl}\end{array}$ & In situ combustion & $\begin{array}{l}0.5 \% \mathrm{CO}, 0.5 \% \quad \mathrm{O}_{2}, 7.5 \% \\
\mathrm{CO}_{2}, 10 \% \mathrm{H}_{2} \mathrm{O}, 50 \% \mathrm{H}_{2}-\mathrm{N}_{2} \\
205{ }^{0} \mathrm{C}, 7000 \mathrm{~h}^{-1}\end{array}$ & $\begin{array}{l}99 \% \text { conversion, influences the dispersion of } \\
\mathrm{CuO} \& \text { ceria, lowers the activity of } \mathrm{H}_{2} \text { oxida- } \\
\text { tion \& wide temp range. }\end{array}$ & Zeng (2008) [112] \\
\hline $\mathrm{CuO}-\mathrm{ZnO} / \mathrm{TiO}_{2}$ & Co-precipitation & $\begin{array}{l}1.2 \% \mathrm{CO}, 1.2 \% \mathrm{O}_{2} \& 50 \% \\
\mathrm{H}_{2}-\mathrm{He}, 65-240^{\circ} \mathrm{C}, 18000 \mathrm{~h}^{-1}\end{array}$ & $\begin{array}{l}96 \% \text { conversion, stable \& compa- rable per- } \\
\text { formance with binary systems } \mathrm{CuO} / \mathrm{ZnO} \& \\
\mathrm{CuO} / \mathrm{TiO}_{2} \text {. }\end{array}$ & $\begin{array}{l}\text { Moretti (2008) } \\
{[114]}\end{array}$ \\
\hline $\begin{array}{l}\text { Co-promoted } \mathrm{CuO} \text { - } \\
\mathrm{CeO}_{2} / \mathrm{Y}^{-} \mathrm{Al}_{2} \mathrm{O}_{3}\end{array}$ & Impregnation & $\begin{array}{l}53 \% \mathrm{H}_{2}, 13 \% \mathrm{CO}_{2}, 1.3 \% \mathrm{CH}_{4} \\
0.5-1 \% \mathrm{CO}, 20-30 \% \mathrm{H}_{2} \mathrm{O} \\
205-230^{0} \mathrm{C}\end{array}$ & $\begin{array}{l}>99 \% \text { conversion, small amount of Co increases } \\
\text { the selectivity and activity of the catalyst. }\end{array}$ & Park (2004) [123] \\
\hline $\begin{array}{l}10 \% \mathrm{Co} / \mathrm{CeO}_{2} \text { nanopar- } \\
\text { ticles }\end{array}$ & $\begin{array}{l}\text { Incipient wetness, } \\
\text { Impregnation }\end{array}$ & $\begin{array}{l}1 \% \mathrm{CO}, \quad 1 \% \mathrm{O}_{2}, \quad 60 \% \\
\mathrm{H}_{2}, 1 \% \mathrm{CO}_{2}, 175 \& \quad 275 \quad{ }^{\circ} \mathrm{C} \\
30000 \mathrm{ml} / \mathrm{g} \mathrm{h}\end{array}$ & $\begin{array}{l}\approx 100 \% \text { conversion, stable, presence of excess } \mathrm{H}_{2} \\
\text { decreases the } \mathrm{CO} \text { oxidation rate }\end{array}$ & Woods (2010) [8] \\
\hline
\end{tabular}


Table 2.1. (continued)

\begin{tabular}{|c|c|c|c|c|}
\hline \multicolumn{5}{|c|}{ Gold based catalysts } \\
\hline $1 \% \mathrm{Au} / \mathrm{CeO}_{2}$ & $\begin{array}{l}\text { a. Impregnation } \\
\text { b.Co-precip. } \\
\text { c. Sol-gel }\end{array}$ & $\begin{array}{l}1 \% \mathrm{CO}, 0.5-2 \% \mathrm{O}_{2} 2 \% \mathrm{CO}_{2} \\
2-6 \% \mathrm{H}_{2} \mathrm{O}, 40 \% \mathrm{H}_{2}-\mathrm{He}, 110 \\
{ }^{0} \mathrm{C}, 30000 \mathrm{ml} / \mathrm{g} \mathrm{h}\end{array}$ & $\begin{array}{l}98 \% \text { conversion, stable, co-precip } \mathrm{Au} / \mathrm{CeO}_{2} \\
\text { exhibiting the highest activities. No signify- } \\
\text { cant effect of } \mathrm{H}_{2} \mathrm{O} \& \mathrm{CO}_{2} \text { on } \mathrm{CO} \text { selectivity. }\end{array}$ & $\begin{array}{l}\text { Luengnaru- } \\
\text { emitchai (2004) } \\
\text { [75] }\end{array}$ \\
\hline $\begin{array}{l}\text { Pt-Au bimetallic } \\
\text { catalyst }\end{array}$ & $\begin{array}{l}\text { a. Impregnation on sol- } \\
\text { gel, b. Single step sol- } \\
\text { gel }\end{array}$ & $\begin{array}{l}0.5-1 \% \mathrm{CO}, 1 \% \mathrm{O}_{2}, 40 \% \mathrm{H}_{2} \\
0-10 \% \mathrm{H}_{2} \mathrm{O} \text {, and } 0-25 \% \mathrm{CO}_{2} \\
50-90{ }^{\circ} \mathrm{C}\end{array}$ & $\begin{array}{l}90 \% \text { conversion, Catalyst prepared by single } \\
\text { step sol- gel method exhibited an excellent } \\
\text { catalytic activity for PROX of CO. }\end{array}$ & $\begin{array}{l}\text { Monyanon } \\
(2007)[87]\end{array}$ \\
\hline nano-gold catalysts & Photo-deposition (PD) & $\begin{array}{l}1.33 \% \mathrm{CO}, 1.33 \% \mathrm{O}_{2} \\
65.33 \% \mathrm{H}_{2}-\mathrm{He}, 50{ }^{\circ} \mathrm{C}, 30000 \\
\mathrm{ml} / \mathrm{g} \mathrm{h}\end{array}$ & $\begin{array}{l}99 \% \text { conversion, not stable, PD method facili- } \\
\text { tates to prepare gold particles as small as } 1.5 \\
\mathrm{~nm} \text {. Very active and selective in PROX. }\end{array}$ & Chang [2008] [77] \\
\hline $\mathrm{Au} / \mathrm{CeO}_{2}-\mathrm{Co}_{3} \mathrm{O}_{4}$ & $\begin{array}{l}\text { Deposition- } \\
\text { precipitation }\end{array}$ & $\begin{array}{l}1 \% \mathrm{CO}, 1 \% \mathrm{O}_{2}, 50 \% \mathrm{H}_{2}, 80 \\
{ }^{0} \mathrm{C}, 30000 \mathrm{ml} / \mathrm{g} \mathrm{h}\end{array}$ & $\begin{array}{l}91 \% \text { conversion shows higher activity than } \mathrm{Au} / \\
\mathrm{Co}_{3} \mathrm{O}_{4}, \mathrm{Au} / \mathrm{CeO}_{2} \& \mathrm{CeO}_{2}-\mathrm{Co}_{3} \mathrm{O}_{4} \text { composite ox- } \\
\text { ide. }\end{array}$ & Wang (2008) [76] \\
\hline $\begin{array}{l}\text { Au/doped } \\
\text { Ceria }\end{array}$ & $\begin{array}{l}\text { Deposition- } \\
\text { precipitation }\end{array}$ & $\begin{array}{l}1 \% \mathrm{CO}, 1.25 \% \mathrm{O}_{2}, 50 \% \mathrm{H}_{2} \\
15 \% \mathrm{CO}_{2} 10 \% \mathrm{H}_{2} \mathrm{O}-\mathrm{He}, 500^{\circ} \mathrm{C}\end{array}$ & $\begin{array}{l}96.6 \% \text { conversion, improved tolerance towards } \\
\text { the presence of } \mathrm{CO}_{2} \text { and } \mathrm{H}_{2} \mathrm{O} \text { in the PROX } \\
\text { feed. }\end{array}$ & $\begin{array}{l}\text { Manzoli (2008) } \\
{[89]}\end{array}$ \\
\hline $\begin{array}{l}\mathrm{Au} / \mathrm{ZnO} \text { nanocatal- } \\
\text { ysts }\end{array}$ & $\begin{array}{l}\text { Ultrasonication } \\
\text { Double impregn. } \\
\text { Washing dry. }\end{array}$ & $5 \% \mathrm{CO}, 10 \% \mathrm{O}_{2}-\mathrm{He}, 200^{\circ} \mathrm{C}$ & $\begin{array}{l}100 \% \text { conversion, best results obtained with } \\
\mathrm{ZnO} \text { prepared by chemical vapour-deposition } \\
\text { with Au loaded by ultrasonication }\end{array}$ & $\begin{array}{l}\text { Carabineiro } \\
(2010)[79]\end{array}$ \\
\hline $\begin{array}{l}\mathrm{Cu}-\mathrm{Au} / \mathrm{Al}_{2} \mathrm{O}_{3} \text { cata- } \\
\text { lysts }\end{array}$ & $\begin{array}{l}\text { Deposition- } \\
\text { precipitation }\end{array}$ & $\begin{array}{l}1 \% \mathrm{CO}, 0.5-1.5 \% \mathrm{O}_{2} \\
30 \% \mathrm{H}_{2}, 0-30 \% \mathrm{CO}_{2}, 0-10 \% \\
\mathrm{H}_{2} \mathrm{O}-\mathrm{He}, 50{ }^{\circ} \mathrm{C}\end{array}$ & $\begin{array}{l}97 \% \text { conversion, } \mathrm{H}_{2} \mathrm{O} \text { positively effects } \mathrm{CO} \\
\text { conversion \& selecti- vity, } \mathrm{CO}_{2} \text { diminishes the } \\
\text { same }\end{array}$ & Mozer (2009)[85] \\
\hline $\begin{array}{ll}\mathrm{Au} / \mathrm{ZnO} & \mathrm{Au} / \mathrm{ZnO}- \\
\mathrm{Fe}_{2} \mathrm{O}_{3} & \end{array}$ & $\begin{array}{l}\text { Photo-deposition under } \\
\text { UV-light }\end{array}$ & $\begin{array}{l}1 \% \mathrm{CO}, 1 \% \mathrm{O}_{2}, 40 \% \mathrm{H}_{2}, 0- \\
10 \% \mathrm{CO}_{2}, 10 \% \mathrm{H}_{2} \mathrm{O}-\mathrm{He}, 50^{\circ} \mathrm{C}\end{array}$ & $\begin{array}{l}100 \% \text { conversion, catalysts exhibited excellent } \\
\text { activity, even in presence of } \mathrm{CO}_{2} \& \mathrm{H}_{2} \mathrm{O}\end{array}$ & $\begin{array}{l}\text { Naknam } \quad(2009) \\
{[92]}\end{array}$ \\
\hline \multicolumn{5}{|c|}{ Supported noble metal catalysts } \\
\hline $\mathrm{Ir} / \mathrm{CeO}_{2}$ & $\begin{array}{l}\text { a. Impregnation } \\
\text { b. DP c. HDP }\end{array}$ & $\begin{array}{l}2 \% \mathrm{CO}, 1 \% \mathrm{O}_{2} 40 \% \mathrm{H}_{2} \\
\mathrm{He}, 80^{\circ} \mathrm{c}, 40000 \mathrm{ml} / \mathrm{g} \mathrm{h}\end{array}$ & $\begin{array}{l}70 \% \text { conversion, stable, negligible influence } \\
\text { of } \mathrm{H}_{2} \mathrm{O} \text { on activity, } \mathrm{CO}_{2} \text { affected negatively. }\end{array}$ & Huang (2007) [47] \\
\hline $\begin{array}{l}15 \text { wt. } \% \mathrm{MnO}_{\mathrm{x}} \mathrm{Pt} / \\
\mathrm{Al}_{2} \mathrm{O}_{3}\end{array}$ & $\begin{array}{l}\text { Successive impregna- } \\
\text { tion }\end{array}$ & $\begin{array}{l}1 \% \mathrm{CO}, 1 \% \mathrm{O}_{2}, 60 \% \mathrm{H}_{2}-\mathrm{He} 160 \\
{ }^{0} \mathrm{C}, 12000 \mathrm{~h}^{-1}\end{array}$ & $\begin{array}{l}100 \% \text { conversion, stable, } \mathrm{CO}_{2} \text { enhances activ- } \\
\text { ity, } \mathrm{H}_{2} \mathrm{O} \text { inhibits activity with higher MnOx } \\
\text { content }\end{array}$ & $\begin{array}{l}\text { Ayastuy (2007) } \\
{[53]}\end{array}$ \\
\hline $\begin{array}{l}\text { A-type zeolite- } \\
\text { supported Pt }\end{array}$ & Sol-gel & $\begin{array}{l}40 \% \mathrm{H}_{2}, 1 \% \mathrm{CO}, 1 \% \mathrm{O}_{2}, 0-10 \\
\% \mathrm{CO}_{2}, 0-10 \% \mathrm{H}_{2} \mathrm{O}, 100- \\
300{ }^{\circ} \mathrm{C}\end{array}$ & $\begin{array}{l}\sim 95 \% \text { conversion, Stable, no effect of } \mathrm{CO}_{2} \text { on the } \\
\text { conversion; } \mathrm{H}_{2} \mathrm{O} \text { depressed the selectivity and } \\
\text { conversion both. }\end{array}$ & $\begin{array}{l}\text { Luengnaru- } \\
\text { emitchai }(2008) \\
\text { [71] }\end{array}$ \\
\hline $\begin{array}{l}\text { Electrochemically } \\
\text { promoted Pt }\end{array}$ & Electrochemical & $\begin{array}{l}1 \% \mathrm{CO}, 1 \% \mathrm{O}_{2}, 40 \% \mathrm{H}_{2-} \\
\mathrm{He}, 195^{\circ} \mathrm{C}\end{array}$ & $\begin{array}{l}83 \% \text { conversion, activity \& selecti- vity strongly } \\
\text { enhanced by electro chemical promotion. }\end{array}$ & $\begin{array}{l}\text { Consuegra }(2010) \\
{[74]}\end{array}$ \\
\hline $\mathrm{Pt}-\mathrm{Fe} /$ mordenite & Ion-exchange & $\begin{array}{l}1 \% \mathrm{CO}, 1 \% \mathrm{O}_{2}, 20 \% \mathrm{CO}_{2} \\
20 \% \mathrm{H}_{2} \mathrm{O}, 68 \% \mathrm{H}_{2}, 150^{\circ} \mathrm{C} \\
50000 \mathrm{~h}^{-1}\end{array}$ & $\begin{array}{l}100 \% \text { conversion,Stable,extremely high reac- } \\
\text { tivity \& selectivity }\end{array}$ & $\begin{array}{l}\text { Kotobuki (2005) } \\
{[63]}\end{array}$ \\
\hline $\mathrm{Pt}-\mathrm{Co}-\mathrm{Al}_{2} \mathrm{O}_{3}$ aerogel & Sol-gel impregnation & $\begin{array}{l}1 \% \mathrm{H}_{2}, 0.1 \% \mathrm{CO}, 0.1 \% \mathrm{O}_{2}-\mathrm{N}_{2} \\
75-200{ }^{\circ} \mathrm{C}, 23100 \mathrm{~h}^{-1}\end{array}$ & $\begin{array}{l}99 \% \text { conversion, Co increases activity. Sol-gel } \\
\text { > impregnation method. }\end{array}$ & Kwak (2005) [68] \\
\hline $\begin{array}{l}\text { K-promoted } \\
\text { Rh/USY }\end{array}$ & Impregnation & $\begin{array}{l}75 \% \mathrm{H}_{2}, 0.2 \% \mathrm{CO} \quad 0.2 \% \mathrm{O}_{2}, \\
140^{\circ} \mathrm{C}\end{array}$ & $\begin{array}{l}>99.5 \% \text { conversion, potassium increases activ- } \\
\text { ity of } \mathrm{CO} \text { oxidation }\end{array}$ & Tanaka (2003) [50] \\
\hline
\end{tabular}

This, $\mathrm{Pt}-\mathrm{Ni} / \mathrm{Y}-\mathrm{Al}_{2} \mathrm{O}_{3}$ catalyst showed the best performance even in the presence of 2 vol $\% \mathrm{H}_{2} \mathrm{O}$ and 20 vol\% $\quad \mathrm{CO}_{2}$. The conflicting conclusions regarding performance of precious metal Vs base metal catalysts for CO-PROX by various authors may be due to different experimental conditions followed. Table 2.1 provides a list of representative recent literature survey at a glance on CO-PROX in $\mathrm{H}_{2}$ rich gases.

\section{Conclusions}

It can be concluded after thorough scanning of the literature that among all the hydrogen purification methods, preferential oxidation of $\mathrm{CO}$ shows the best result for $\mathrm{CO}$ removal up to the trace amount. Conventionally noble metal based (Pt, Pd, Rh, Ir, supported) catalysts are used for CO-PROX besides these gold based and base metal oxide ( $\mathrm{Cu}, \mathrm{Ce}, \mathrm{Co}, \mathrm{Zr}, \mathrm{Zn}$ supported etc.) catalysts 
are also used. The presence of $\mathrm{CO}_{2}$ and $\mathrm{H}_{2} \mathrm{O}$ in feed stream reduces the activity of noble metal and gold catalysts. Au/ceria catalysts are significantly more active, while $\mathrm{CuO} /$ ceria ones are remarkably more selective. $\mathrm{CuO}-\mathrm{CeO}_{2}$ modified with $\mathrm{Zr}$ and $\mathrm{Sn}$ shows better results than $\mathrm{Pt}$ supported noble metal catalysts. Thus $\mathrm{CuO}-\mathrm{CeO}_{2}$ based catalysts gives most appropriate result for CO-PROX, these are the cheaper than other classes of the catalysts and easily available hence it also reduces the cost of PEMFC. The catalytic properties are strongly affected by the synthesis procedures of the base metal catalysts. Reported ranking order of the preparation methods of the $\mathrm{CuO}-\mathrm{CeO}_{2}$ catalyst in $\mathrm{CO}$ oxidation activity is as follows: urea-nitrates combustion $>$ citrate-hydrothermal $>$ coprecipitation $>$ impregnation method.

\section{References}

[1] Gray, P.G.; and Frost, J.C. 1998. Impact on clean energy in road transportation. Energy Fuels 12: 1121-1129.

[2] Docter, A.; and Lamm, A. 1999. Gasoline fuel cell systems. J. Power Sources 84: 194-200.

[3] Ghenciu, A.F. 2002. Review of fuel processing catalysts for hydrogen production in PEM fuel cell systems. Curr. Opin. Solid State Mater. Sci. 6: 389-399.

[4] Park, E. D.; Lee, D.; and Lee, H. C. 2009. Recent progress in selective $\mathrm{CO}$ removal in a $\mathrm{H}_{2}$-rich stream. Catal. Today 139: 280-290.

[5] Fuel cells handbook. 2000. EG\&G Services, Parson (Ed), Science Applications International Corporation-US Department of Energy, Office of Fossil Energy, National Energy Technology Laboratory, 5th Ed.

[6] Acres, G.J.K.; Frost, J.C.; Hards, G.A.; Potter, R.J.; Ralph, T.R.; and Thompsett, D. 1997. Electrocatalysts for fuel cells. Catal. Today 38: 393-400

[7] Ralph, T.R.; and Hards, G. 1998. Fuel cells: clean energy production for the new millennium. Chem. Eng. (London) 8: 334-335.

[8] Woods, M. P.; Gawade, P.; Tan, B.; and Ozkan, U.S. 2010. Preferential oxidation of carbon monoxide on $\mathrm{Co} / \mathrm{CeO}_{2}$ nanoparticles. Appl Catal B: Environ. 97: 2835 .

[9] Cortes, A. G.; Marquez, Y.; Alatorre, J. A.; and Diaz, G. 2008. Selective $\mathrm{CO}$ oxidation in excess of $\mathrm{H}_{2}$ over highsurface area $\mathrm{CuO} / \mathrm{CeO}_{2}$ catalysts. Catal. Today 133-135: 743-749.

[10] Schonbrod, B.; Marino; Baronetti; F.; and Laborde, M. 2009. Catalytic performance of a copper-promoted $\mathrm{CeO}_{2}$ catalyst in the $\mathrm{CO}$ oxidation: Influence of the operating variables and kinetic study. Int. J. Hydrogen Energy 34: 4021-4028.

[11] Al-Ghamdi, M. S. 2006. Studies on Catalysts for Preferential Oxidation of $\mathrm{CO}$ in $\mathrm{H}_{2}$-Rich Gas Mixture. M.S. Thesis. The Research Institute King Fahd University of Petroleum \& Minerals Dhahran, Saudi Arabia.
[12] Caputo, T. 2005. $\mathrm{CuO} / \mathrm{CeO}_{2}$ catalysts for the preferential oxidation of $\mathrm{CO}$ in $\mathrm{H}_{2}$ rich mixture for fuel cell applications. Ph.D Thesis. Department of Chemical and Biological Engineering of the Northwestern University (Evanston, IL, USA).

[13] Chin, P. 2004. Preferential Oxidation of Carbon Monoxide on Structured Supports. Master's Thesis North Carolina State University.

[14] Lakshmanan, P. 2006. Design of nanosized ceriazirconia mixed oxides for catalytic applications, M.Sc. Thesis. Indian Institute of Chemical Technology Hyderabad, India.

[15] Zhang, Y.; Ruhl, J.; Brenner, A.M.; and Gittleman, C.S. 2005. Carbon monoxide clean-up in a PEM fuel cell system. US 2005/0193627 A1.

[16] Abdo, S.F.; Deboy, C.A.; and Schroeder, G.F. 2003. Preferential oxidation catalyst US 6573214 B2.

[17] Shore, L.; and Farrauto, R.J. 2006. Preferential oxidation catalyst containing platinum, copper \& iron. US 2006/0276332 A1.

[18] Lee, H-C; Kim, S.H.; Lee, D-H; Park, E-D; and Ko, E-Y. 2008. Catalyst for oxidizing monoxide and method of preparing the same US 2008/0008926 A1.

[19] We, M-C; and Weissman, J.G. 2006. Selective carbon monoxide oxidation catalyst method of making the same \& systems using the same. US 7147947 B2.

[20] Vanderspurt, T.H.; Wijzer, F.; Tang, X.; Leffler, M.P.; Willigan, R.R.; Newman, C.A.; Radhakrishnan, R.; Feng, F.; Laube, B. L.; Dardas, Z.; Opalka, S.M.; and She, Y. 2007. Ceria based mixed-metal of structure, including method of making \& use. US $7166263 \mathrm{B2}$.

[21] Kim, M.C.; Dong, Y.; Gu, S.; Si, C.; Do, C.; Son, I.H.; Dong, S.; Si, U.; and Do, G. 2007. Preferential oxidation catalyst and process for preparing the same. US 7247599 B2.

[22] Freemantle, M. 2005. Membranes for gas separation. Chem. Eng. News 83: 49-57.

[23] Adhikari, S.; and Fernando, S. 2006. Hydrogen membrane separation techniques. Ind. Eng. Chem. Res. 45: 875-881.

[24] Ockwig, N. W.; and Nenoff, T. M. 2007. Membranes for Hydrogen Separation. Chem. Rev. 107: 4078-4110.

[25] Lu, G.Q.; Diniz da Costa, J.C.; Duke, M.; Giessler, S.; Socolowe, R.; Williams, R.H.; and Kreutz, T. 2007. Inorganic membranes for hydrogen production and purification: A critical review and perspective. J. Colloid Interface Sci. 314: 589-603

[26] Adams, T. M.; and Mickalonis, J. 2007. Hydrogen permeability of multiphase $\mathrm{V}-\mathrm{Ti}-\mathrm{Ni}$ metallic membranes. Mater. Lett. 61: 817-820

[27] Roa, F.; Block, M.J.; and Way, J.D. 2002. The influence of alloy composition on the $\mathrm{H}_{2}$ flux of composite $\mathrm{Pd}-\mathrm{Cu}$ membranes. Desalination 147: 411-416.

[28] Sotowa, K.I.; Hasegawa, Y.; Kusakabe, K.; and Morooka, S. 2002. Enhancement of $\mathrm{CO}$ oxidation by use of $\mathrm{H}_{2}$ selective membranes impregnated with noble-metal catalysts. Int. J. Hydrogen Energy 27: 339-346.

[29] Bernardo, P.; Algieri, C.; Barbieri, G.; and Drioli, E. 2008. Hydrogen purification from carbon monoxide by 
means of selective oxidation using zeolite catalytic membranes. Sep. Purif. Technol. 62:629-635.

[30] Varela-Gandía, F.J.; Berenguer-Murcia, A.; LozanoCastelló, D.; and Cazorla-Amorós, D. 2010. Hydrogen purification for PEM fuel cells using membranes prepared by ion-exchange of Na-LTA/carbon membranes; J. Membr. Sci. 351:123-130

[31] Takenaka, S.; Shimizu, T.; and Otsuka, K. 2004. Complete removal of carbon monoxide in hydrogen-rich gas stream through methanation over supported metal catalysts; Int. J. Hydrogen Energy 29:1065-1073.

[32] Dagle, R. A.; Wang, Y.; Xia, G-G; Strohm, J. J.; Holladay, J.; and Palo, D. R. 2007. Selective CO methanation catalysts for fuel processing applications. Appl. Catal. A: General 326:213-218.

[33] Chen, S.Q.; and Liu, Y. 2009. $\mathrm{LaFe}_{y} \mathrm{Ni}_{1-\mathrm{y}} \mathrm{O}_{3}$ supported nickel catalysts used for steam; reforming of ethanol. Int. J. Hydrogen Energy 34:4735-4746.

[34] Profeti L.P.R; Dias, J.A.C; Assaf, J.M.; and Assaf, E.M. 2009. Hydrogen production by steam reforming of ethanol over Ni-based catalysts promoted with noble metals. J. of Power Sources 190: 525-533.

[35] Galletti, C.; Specchia, S.; Saracco, G.; and Specchia, V. 2010. CO-selective methanation over $\mathrm{Ru}-\mathrm{YAl}_{2} \mathrm{O}_{3}$ catalysts in $\mathrm{H}_{2}$-rich gas for PEMFC applications. Chem. Eng. Sci. 65:590-596.

[36] Xua, G.; Chen, X.; and Zhang, Z-G. 2006. Temperaturestaged methanation: An alternative method to purify hydrogen-rich fuel gas for PEMFC. Chem. Eng. J. 121: 97-107.

[37] Li, Z.; Mi, W.; Liu, S.; and Su, Q.2010. CO deep removal with a method of two-stage methanation; Int. J. Hydrogen Energy 35:2820-2823.

[38] Sunny, E. I.; Mohammed, A. B.; Daud, W. R.; Kadhum, A. H.; Fisal, Z.; and Sheriff, A. M. 2000. Removal of CO from process with $\mathrm{Sn}$-activated carbon in pressure swing adsorption; Journal of chemical technology and biotechnology 75: 803-811.

[39] Teiseh, E.; and Capareda, S. 2010 Purification of Hydrogen from a Thermo-chemical Process using a Single-Column Pressure Swing Adsorption System with Compound Adsorbent. An ASABE Meeting Presentation Paper Number: 1009782.

[40] Barelli, L.; Bidini, G.; Gallorini, F.; and Servili, S. 2008. Hydrogen production through sorption-enhanced steam methane reforming and membrane technology: A review. Energy 33: 554-570.

[41] Tagliabue, M.; Farrusseng, D.; Valencia, S.; Aguado, S.; Ravon, U.; Rizzo, C.; Corma, A.; and Mirodatos, C. 2009. Natural gas treating by selective adsorption: Material science and chemical engineering interplay. Chem. Eng.J. 155: 553-566.

[42] Sircar, S.; and Golden, T. C. 2000. Purification of Hydrogen by Pressure Swing Adsorption. Sep. Sci. Technol. 35: 5, 667-687.

[43] Yang, S-I; Choi, D-Y; Jang, S-C; Kim, S-H; and Choi, D$\mathrm{K}$ 2008. Hydrogen separation by multi-bed pressure swing adsorption of synthesis gas. Adsorption 14: 583590

[44] Majlan, E. H.; Daud, W. R. W.; Iyuke, S. E.; Mohamad, A. B.; Amir, A.; Adhum, H. K.; Mohammad, A.W.; Takriff, M. S.; and Bahaman N. 2009. Hydrogen purification using compact pressure swing adsorption system for fuel cell. Int. J. Hydrogen Energy 34: 27712777.

[45] López, I.; Valdés-Solís, and T.; Marbán, G. 2008. An attempt to rank copper-based catalysts used in the COPROX reaction. Int. J. Hydrogen Energy 33: 197-205.

[46] Hulteberg, P.C.; Brandin, J.G.M.; Silversand, F.A.; and Lundberg, M.2005. Preferential oxidation of carbon monoxide on mounted and unmounted noble-metal catalysts in hydrogen-rich streams. Int. J. Hydrogen Energy 30:1235-1242.

[47] Huang, Y.; Wang, A.; Wang, X.;and Zhang, T. 2007. Preferential oxidation of $\mathrm{CO}$ under excess $\mathrm{H}_{2}$ conditions over iridium catalysts; Int. J. Hydrogen Energy 32: 3880 -3886 .

[48] Huang, Y.; Wang, A.; Li, L.; Wang, X.; Su, D.; and Zhang T. 2008. Ir-in-ceria: A highly selective catalyst for preferential CO oxidation. J. Catal. 255: 144-152.

[49] Zhang, W.; Huang, Y.; Wang, J.; Liu, K.; Wang, X.; Wang, A.; and Zhang, T. 2010. $\mathrm{IrFeO}_{\mathrm{x}} / \mathrm{SiO}_{2} \mathrm{~A}$ highly active catalyst for preferential $\mathrm{CO}$ oxidation in $\mathrm{H} 2$. Int. J. Hydrogen Energy 35: 3065-3071.

[50] Tanaka, H.; Ito, S.; Kameoka, S.; Tomishige, K.; and Kunimori, K. 2003. Catalytic performance of Kpromoted Rh/USY catalysts in preferential oxidation of CO in rich hydrogen. Appl Catal. A: general 250: 255263.

[51] Chin, S.Y.; Alexeev, O.S.; and Amiridis, M.D. 2005 Preferential oxidation of $\mathrm{CO}$ under excess $\mathrm{H}_{2}$ conditions over Ru catalysts. Appl. Catal. A: general 286: 157-166.

[52] Kim, Y.H.; Park, E.D.; Lee, H.C.; and Lee, D. 2009. Selective $\mathrm{CO}$ removal in a $\mathrm{H}_{2}$-rich stream over supported $\mathrm{Ru}$ catalysts for the polymer electrolyte membrane fuel cell (PEMFC); Appl. Catal. A: general 366: 363-369.

[53] Ayastuy, J.L.; Gonzalez-Marcos, M.P.; GonzalezVelasco, J.R.; and Gutierrez-Ortiz, M.A. 2007 $\mathrm{MnO}_{\mathrm{x}} / \mathrm{Pt} / \mathrm{Al}_{2} \mathrm{O}_{3}$ catalysts for $\mathrm{CO}$ oxidation in $\mathrm{H} 2$-rich streams. Appl. Catal. B: environ.70: 532-541.

[54] Jo, M-C; Kwon, G-H; Li, W.; and Lane, A. M. 2009. Preparation and characteristics of pretreated Pt/alumina catalysts for the preferential oxidation of carbon monoxide. J. Ind. Eng. Chem.15: 336-341.

[55] Huanling, L.; Lei, M.; Saibing, S.; Zenghe, L.; Aiqin, W.; Yanqiang, H.; and Ta, Z. 2007. Preferential CO Oxidation on Ce-Promoted $\mathrm{Pt} / \mathrm{Y}-\mathrm{Al}_{2} \mathrm{O}_{3}$ Catalysts under H2-Rich Atmosphere. Chin. J. Catal. 28(12): 1077-1082.

[56] Atalik, B.; and Uner, D. 2006. Structure sensitivity of selective $\mathrm{CO}$ oxidation over $\mathrm{Pt} / \mathrm{Y}-\mathrm{Al}_{2} \mathrm{O}_{3}$. J. of Catal. 241: 268-275.

[57] Wootsch, A.; Descorme, C.; and Duprez, D. 2004 Preferential oxidation of carbon monoxide in the presence of hydrogen (PROX) over ceria-zirconia and alumina-supported Pt catalysts. J. of Catal. 225: 259. 266.

[58] Kwak, C.; Park, T.J.; and Suh, D.J. 2005. Effects of sodium addition on the performance of $\mathrm{PtCo}_{\mathrm{Al}} \mathrm{Al}_{2} \mathrm{O}_{3}$ catalysts for preferential oxidation of carbon monoxide from hydrogen-rich fuels; Appl. Catal. A: general 278: 181-186. 
[59] Kuriyama, M.; Tanaka, H.; Ito, S.i; Kubota, T.; Miyao, T.; Naito, S.; Tomishige K.; and Kunimori, K. 2007. Promoting mechanism of potassium in preferential $\mathrm{CO}$ oxidation on $\mathrm{Pt}_{\mathrm{Al}} \mathrm{Al}_{3}$. J. of Catal. 252: 39-48.

[60] Kotobuki, M.; Watanabe, A.; Uchida, H.; Yamashita, H.; and Watanabe, M. 2006. High catalytic performance of Pt-Fe alloy nanoparticles supported in mordenite pores for preferential $\mathrm{CO}$ oxidation in H2-rich gas. Appl. Catal. A: general 307:275-283.

[61] Maeda, N.; Matsushima, T.; Kotobuki, M.; Miyao, T.; Uchida, H.; Yamashita, H.; and Watanabe, M. 2009. $\mathrm{H}_{2} \mathrm{O}$-tolerant monolithic catalysts for preferential oxidation of carbon monoxide in the presence of hydrogen; Appl. Catal. A: general 370: 50-53.

[62] Chin, P.; Sun, X.; Roberts, G.W. and Spivey, J.J. 2006. Preferential oxidation of carbon monoxide with ironpromoted platinum catalysts supported on metal foams. Appl. Catal. A: general 302: 22-31.

[63] Kotobuki, M.; Watanabe, A.; Uchida, H.; Yamashita, H.; and Watanabe, M. 2005. Pt-Fe/mordenite catalysts reaction mechanism of preferential oxidation of carbon monoxide on $\mathrm{Pt}, \mathrm{Fe}$, and $\mathrm{Pt}-\mathrm{Fe} /$ mordenite catalysts. J of Catal 236: 262-269.

[64] Huang, C-Y; Chen, Y-Y; Su, C-C; and Hsu, C-F. 2007. The cleanup of $\mathrm{CO}$ in hydrogen for PEMFC applications using $\mathrm{Pt}, \mathrm{Ru}, \mathrm{Co}$, and $\mathrm{Fe}$ in PROX reaction. J. of Power Sources 174: 294-301.

[65] Maeda, N.; Matsushima, T.; Uchida, H.; Yamashita, H.; and Watanabe, M. 2008. Performance of Pt$\mathrm{Fe} /$ mordenite monolithic catalysts for preferential oxidation of carbon monoxide in a reformate gas for PEFCs; Appl. Catal. A: general 341: 93-97.

[66] Tanaka, H.; Kuriyama, M.; Ishida, Y.; Ito, S.; Tomishige, K. and Kunimori K. 2008. Preferential CO oxidation in hydrogen-rich stream over Pt catalysts modified with alkali metals Part I. Catalytic performance; Appl. Catal. A: general 343: 117-124.

[67] S., Guerrero; J.T., Miller; and E.E., Wolf. 2007. Activity and selectivity control by niobium for the preferential oxidation of co on pt supported catalysts; Appl. Catal. A: general 328: 27-34.

[68] Kwak, C.; Park, T.J.; and Suh, D.J. 2005. Preferential oxidation of carbon monoxide in hydrogen-rich gas over platinum-cobalt-alumina aerogel catalysts; Chem. Eng. Sci. 60: 1211-1217.

[69] Choi, J.; Shin, C. B.; Suh, D.J. 2008. Co-promoted Pt catalysts supported on silica aerogel for preferential oxidation of CO Catal. Commun. 9: 880-885.

[70] Sebastian, V.; Irusta, S.; Mallada, R.; and Santamarıa, J. 2009. Selective oxidation of $\mathrm{CO}$ in the presence of $\mathrm{H}_{2}$, $\mathrm{CO}_{2}$ and $\mathrm{H}_{2} \mathrm{O}$, on different zeolite-supported $\mathrm{Pt}$ catalysts. Appl. Catal. A: general 366: 242-251.

[71] Luengnaruemitchai, A.; Nimsuk, M.; Naknam, P.; Wongkasemjit, S.; Osuwan, S. 2008. A comparative study of synthesized and commercial A-type zeolitesupported Pt catalysts for selective $\mathrm{CO}$ oxidation in $\mathrm{H}_{2}$ rich stream. Int. J. Hydrogen Energy 33: 206-213

[72] Naknam, P.; Luengnaruemitchai, A.; Wongkasemjit, S.; and Osuwan, S. 2007. Preferential catalytic oxidation of carbon monoxide in presence of hydrogen over bimetallic AuPt supported on zeolite catalysts. J. of Power Sources 165: 353-358.
[73] Komatsu, T.; and Tamura, A. 2008. Pt ${ }_{3}$ Co and $\mathrm{PtCu}$ intermetallic compounds: Promising catalysts for preferential oxidation of $\mathrm{CO}$ in excess hydrogen. J. of Catal. 258: 306-314.

[74] de Lucas-Consuegra, A.; Princivalle, A.; Caravaca, A.; Dorado, F.; Guizard, C.; Valverde, J.L.; and Vernoux, P. 2010. Preferential CO oxidation in hydrogen-rich stream over an electrochemically promoted Pt catalyst. Appl. Catal. B: environ. 94: 281-287.

[75] Luengnaruemitchai, A.; Osuwan, S.; Gulari E. 2004. Selective catalytic oxidation of $\mathrm{CO}$ in the presence of $\mathrm{H}_{2}$ over gold catalyst. Int. J. Hydrogen Energy 29: 429-435.

[76] Wang, H.; Zhu, H.; Qin, Z.; Wang, G.; Liang, F.; Wang, J. 2008. Preferential oxidation of $\mathrm{CO}$ in $\mathrm{H}_{2}$ rich stream over $\mathrm{Au} / \mathrm{CeO}_{2}-\mathrm{Co}_{3} \mathrm{O}_{4}$ catalysts. Catal. Commun. 9: 1487-1492.

[77] Chang, L.H.; Yeh, Y.L.; Chen, Y.W. 2008. Preferential oxidation of $\mathrm{CO}$ in hydrogen stream over nano-gold catalysts prepared by photodeposition method. Int. J. Hydrogen Energy 33: 1965-1974.

[78] Imai, H.; Date, M.; and Tsubota, S. 2008. Preferential Oxidation of $\mathrm{CO}$ in $\mathrm{H}_{2}$-Rich Gas at Low Temperatures over Au Nanoparticles Supported on Metal Oxides. Catal. Lett. 124: 68-73.

[79] Carabineiro, S.A.C.; Machado, B.F.; Bacsa, R.R.; Serp, P.; Drazic, G.; Faria, J.L.; Figueiredo, J.L. 2010. Catalytic performance of $\mathrm{Au} / \mathrm{ZnO}$ nano-catalysts for $\mathrm{CO}$ oxidation; J. of Catal. Article in press.

[80] Quinet, E.; Piccolo, L.; Daly, H.; Meunier, F. C.; Morfin, F.; Valcarcel, A.; Diehl, F.; Avenier, P.; Caps, V.; and Rousset, J-L. 2008. $\mathrm{H}_{2}$-induced promotion of $\mathrm{CO}$ oxidation over unsupported gold Catal Today 138: 4349 .

[81] Liotta, L.F.; Di Carlo, G.; Pantaleo, G.; and Venezia, A.M. 2010. Supported gold catalysts for CO oxidation and preferential oxidation of $\mathrm{CO}$ in $\mathrm{H}_{2}$ stream:Support effect. Catal. Today. Article in press.

[82] Yu, W.Y.; Lee, W. S.; Yang, C.P.; and Wan, B.Z. 2007. Low-temperature preferential oxidation of $\mathrm{CO}$ in a hydrogen rich stream (PROX) over $\mathrm{Au} / \mathrm{TiO}_{2}$ : Thermodynamic study and effect of gold-colloid $\mathrm{pH}$ adjustment time on catalytic activity. J. Chin. Inst. Chem. Eng. 38: 151-160.

[83] Yang, Y-F; Sangeetha, P.; and Chen Y-W. 2009. Au/TiO catalysts prepared by photo-deposition method for selective $\mathrm{CO}$ oxidation in $\mathrm{H}_{2}$ stream; Int. J. Hydrogen Energy. 34: 8912-8920.

[84] Dai, W.; Zheng, X.; Yang, H.; Chen, X.; Wang, X.; Liu, P.; and Fu, X. 2009. The promoted effect of UV irradiation on preferential oxidation of $\mathrm{CO}$ in an $\mathrm{H}_{2}$-rich stream over Au/TiO 2 . J. of Power Sources 188: 507-514.

[85] Mozer, T. S.; Dziubal, D. A.; Vieira, C.T.P.; and Passos, F. B. 2009. The effect of copper on the selective carbon monoxide oxidation over alumina supported gold catalysts. J. of Power Sources 187: 209-215.

[86] Tafin, M.L.; Chaou, A.A.; Morfin, F.; Caps, V.; and Rousset, J.L. 2005. Preferential oxidation of $\mathrm{CO}$ in $\mathrm{H}_{2}$ over highly loaded $\mathrm{Au} / \mathrm{ZrO}_{2}$ catalysts obtained by direct oxidation of bulk alloy. Chem. Commun., 388-390.

[87] Monyanon, S.; Pongstabodee, S.; and Luengnaruemitchai, A. 2007. Preferential oxidation of 
carbon monoxide over Pt, Au monometallic catalyst, and Pt-Au bimetallic catalyst supported on ceria in hydrogen-rich reformate. J. Chin. Inst. Chem. Eng. 38: 435-441.

[88] Ilieva, L.; Pantaleo, G.; Ivanov, I.; Zanella, R.; Venezia, A.M.; and Andreeva D. 2009. A comparative study of differently prepared rare earths-modified ceriasupported gold catalysts for preferential oxidation of CO. Int. J. Hydrogen Energy 34: 6505- 6515

[89] Manzoli, M.; Avgouropoulos, G.; Tabakova, T.; Papavasiliou, J.; Ioannides, T.; and Boccuzzi, F. 2008. Preferential $\mathrm{CO}$ oxidation in H2-rich gas mixtures over Au/doped ceria catalysts. Catal. Today 138: 239-243.

[90] Deng, W.; Jesus, J. D.; Saltsburg, H.; and Stephanopoulos M. F. 2005. Low-content gold-ceria catalysts for the water-gas shift and preferential $\mathrm{CO}$ oxidation reactions. Appl. Catal. A: general 291: 126135 .

[91] Scire, S.; Crisafulli, C.; Minico, S.; Condorelli, G.G.; and Mauro A. D. 2008. Selective oxidation of $\mathrm{CO}$ in $\mathrm{H}_{2}$-rich stream over gold/iron oxide:An insight on the effect of catalyst pre-treatment. J. Mol. Catal. A: Chem. 284: 2432 .

[92] Naknam, P.; Luengnaruemitchai, A.; and Wongkasemjit, S. 2009. Preferential CO oxidation over $\mathrm{Au} / \mathrm{ZnO}$ and $\mathrm{Au} / \mathrm{ZnO}-\mathrm{Fe}_{2} \mathrm{O}_{3}$ catalysts prepared by photodeposition. Int. J. Hydrogen Energy 34: 9838-9846.

[93] Laguna, O.H.; Centeno, M.A.; Arzamendi, G.; Gandía, L.M.; Romero-Sarria, F.; Odriozola, J.A. 2010. Ironmodified ceria and Au/ceria catalysts for Total and Preferential Oxidation of CO (TOX and PROX). Catal. Today Article in press.

[94] Chang, L-H; Sasirekha, N.; Rajesh, B.; and Chen, Y-W. 2007. CO oxidation on ceria- and manganese oxidesupported gold catalysts. Sep. Purif. Technol. 58: 211218.

[95] Marino, F.; Descorme, C.; and Duprez, D. 2005. Supported base metal catalysts for the preferential oxidation of carbon monoxide in the presence of excess hydrogen (PROX). Appl Catal. B: environ.58:75-183.

[96] Ramaswamy, V.; Malwadkar, S.; and Chilukuri, S. 2008. $\mathrm{Cu}-\mathrm{Ce}$ mixed oxides supported on Al-pillared clay: Effect of method of preparation on catalytic activity in the preferential oxidation of carbon monoxide. Appl. Catal. B: environ 84: 21-29.

[97] Liu, Y.; Fu, Q.; and Stephanopoulos, M.F. 2004. Preferential oxidation of $\mathrm{CO}$ in $\mathrm{H}_{2}$ over $\mathrm{CuO}-\mathrm{CeO}_{2}$ catalysts. Catal. Today 93-95: 241-246.

[98] Prasad, R.; and Rattan, G. 2010. Preparation Methods and Applications of $\mathrm{CuO}-\mathrm{CeO}_{2}$ Catalysts: A Short Review. Bull. Chem. React. Eng. Catal. 5 (1): 7 -30.

[99] Avgouropoulos, G.; Ioannides, T.; Matralis, H. 2005. Influence of the preparation method on the performance of $\mathrm{CuO}-\mathrm{CeO}_{2}$ catalysts for the selective oxidation of $\mathrm{CO}$. Appl. Catal. B: environ 56 (2005) 87-93

[100] Liu, Z.; Zhou, and R.; Zheng, X. 2007. Preferential Oxidation of $\mathrm{CO}$ in Excess Hydrogen over $\mathrm{CuO}-\mathrm{CeO}_{2}$ Catalyst Prepared by Chelating Method. J. Nat. Gas Chem. 16: 167-172.

[101] Marino, F.; Baronetti, G.; Laborde, M.; Bion, N.; Le Valant, A.; Epron, F., and Duprez, D. 2008. Optimized
CuO- $\mathrm{CeO}_{2}$ catalysts for CO-PROX reaction. Int. J. Hydrogen Energy 33:1345-1353.

[102] Derekaya, F. B.; Kutar, C.; and Güldür, C. 2009. Selective $\mathrm{CO}$ oxidation over ceria supported $\mathrm{CuO}$ catalysts. Mater. Chem. Phys. 115: 496-501.

[103] Kim, D.H.; Cha, and J.E. 2003. A CuO- $\mathrm{CeO}_{2}$ mixedoxide catalyst for $\mathrm{CO}$ clean-up by selective oxidation in hydrogen-rich mixtures. Catal. Lett. 86: 1-3.

[104] Moreno, M.; Bergamini, L.; Baronetti, G.T.; Laborde, M.A. and Marino, F.J. 2010. Mechanism of CO oxidation over $\mathrm{CuO} / \mathrm{CeO}_{2}$ catalysts. Int. J. Hydrogen Energy 35: 5918-5924

[105] Wu, Z.; Zhu, H.; Qin, Z.; Wang, H.; Ding, J.; Huang, L.; and Wang, J. 2010. CO preferential oxidation in $\mathrm{H}_{2}$-rich stream over a $\mathrm{CuO} / \mathrm{CeO}_{2}$ catalyst with high $\mathrm{H}_{2} \mathrm{O}$ and $\mathrm{CO}_{2}$ tolerance. Fuel Article in press.

[106] Zhang, Y.; Liang, H.; Gao, X.Y.; and Liu, Y. 2009. Threedimensionally ordered macro-porous $\mathrm{CuO}-\mathrm{CeO}_{2}$ used for preferential oxidation of carbon monoxide in hydrogenrich gases. Catal. Commun.. 10: 1432-1436.

[107] Marban, G.; Lopez, I.; and Valdes-Solıs, T. 2009. Preferential oxidation of $\mathrm{CO}$ by $\mathrm{CuO}_{\mathrm{x}} / \mathrm{CeO}_{2}$ nanocatalysts prepared by SACOP Mechanisms of deactivation under the reactant stream. Appl. Catal. A: general 361: 160-169.

[108] Sirichaiprasert, K.; Pongstabodee, S.; and Luengnaruemitchai, A. 2008. Single- and double-stage catalytic preferential $\mathrm{CO}$ oxidation in $\mathrm{H} 2$-rich stream over an a- $\mathrm{Fe}_{2} \mathrm{O}_{3}$-promoted $\mathrm{CuO}-\mathrm{CeO}_{2}$ catalyst; J. Chin. Inst. Chem. Eng 39: 597-607.

[109] Liu, Z.; Zhou, R.; and Zheng, X. 2006. The preferential oxidation of $\mathrm{CO}$ in excess hydrogen: A study of the influence of $\mathrm{KOH} / \mathrm{K}_{2} \mathrm{CO}_{3}$ on $\mathrm{CuO}-\mathrm{CeO}_{2-\mathrm{x}}$ catalysts. $J$. Mol. Catal. A: Chem. 255: 103-108.

[110] Ratnasamy, P.; Srinivas, D.; Satyanarayana, C.V.V.; Manikandan, P.; Senthil Kumaran, R.S.; Sachin, M.; and Shetti, V. N. 2004. Influence of the support on the preferential oxidation of $\mathrm{CO}$ in hydrogen-rich steam reformates over the $\mathrm{CuO}-\mathrm{CeO}_{2}-\mathrm{ZrO}_{2}$ system. J. of Catal. 221: $455-46$.

[111] Pakharukova, V.P.; Moroz, E.M.; Kriventsov, V.V.; Zyuzin, D.A.; Kosmambetova, G.R.; and Strizhak, P.E. 2009. Copper-cerium oxide catalysts supported on monoclinic zirconia: Structural features and catalytic behavior in preferential oxidation of carbon monoxide in hydrogen excess. Appl. Catal. A: general 365: 159-164.

[112] Zeng, S.H.; and Liu, Y. 2010. Nd- or Zr-modified CuO$\mathrm{CeO}_{2} / \mathrm{Al}_{2} \mathrm{O}_{3} / \mathrm{FeCrAl}$ monolithic catalysts for preferential oxidation of carbon monoxide in hydrogen-rich gases. Appl. Surf. Sci. 254: 4879-4885.

[113] Gu, C.; Lu, S.; Miao, J.; Liu, Y.; and Wang, Y. 2010 Mesoemacroporous monolithic $\mathrm{CuO}-\mathrm{CeO}_{2} / \mathrm{a}-\mathrm{Al}_{2} \mathrm{O}_{3}$ catalysts for $\mathrm{CO}$ preferential oxidation in hydrogen-rich gas: Effect of loading methods. Int. J. Hydrogen Energy 35: $6113-6122$.

[114] Moretti, E.; Storaro, L.; Talon, A.; Patrono, P.; Pinzari, F.; Montanari, T.; Ramis, G.; and Lenarda, M. 2008. Preferential CO oxidation (CO-PROX) over CuO$\mathrm{ZnO} / \mathrm{TiO}_{2}$ catalysts Appl. Catal. A: general 344: 165-174

[115] Chen, Y-Z; Liaw, B-J; Chang, W-C; and Huang, C-T. 
2007. Selective Oxidation of $\mathrm{CO}$ in Excess Hydrogen over $\mathrm{CuO} / \mathrm{Ce}_{\mathrm{x}} \mathrm{Zr}_{1-\mathrm{x}} \mathrm{O}_{2} \cdot \mathrm{Al}_{2} \mathrm{O}_{3}$ catalysts. Int. J. Hydrogen Energy 32: 4550-4558.

[116] Hernández, W.Y.; Centeno, M.A.; Romero-Sarria, F.; Ivanova, S.; Montes, M.; and Odriozola, J.A. 2010. Modified cryptomelane-type manganese dioxide nanomaterials for preferential oxidation of $\mathrm{CO}$ in the presence of hydrogen. Catal. Today Article in press.

[117] Valdes-Solıs, T.; Lopez, I.; and Marban, G. 2010. Copper manganite as a catalyst for the PROX reaction.Deactivation studies. Int. J. Hydrogen Energy 35: 1879-1887.

[118] Zhao, Z.; Yung, M.M.; and Ozkan, U.S. 2008. Effect of support on the preferential oxidation of $\mathrm{CO}$ over cobalt catalysts. Catal.. Commun. 9: 1465-1471.
[119] Yung, M.M.; Zhao, Z.;Woods, M.P.; and Ozkan, U.S. 2008. Preferential oxidation of carbon monoxide on $\mathrm{CoO}_{\mathrm{x}} / \mathrm{ZrO}_{2}$. J. Mol. Catal. A: Chem. 279: 1-9.

[120] Guo, Q.; and Liu,Y. 2008. $\mathrm{MnO}_{\mathrm{x}}$ modified $\mathrm{Co}_{3} \mathrm{O}_{4}-\mathrm{CeO}_{2}$ catalysts for the preferential oxidation of $\mathrm{CO}$ in $\mathrm{H} 2$-rich gases. Appl. Catal. B: Environ 82: 19-26.

[121] Guo, Q.; Wu, M.; Liu, Y.; and Bai, X. 2007. Mesoporous $\mathrm{CeO}_{2}$ - Supported $\mathrm{Co}_{3} \mathrm{O}_{4}$ Catalysts for $\mathrm{CO}$ Preferential Oxidation in $\mathrm{H}_{2}$-Rich Gases. Chin. J. Catal. 28(11): 953957.RESEARCH

[122] Park, J.W.; Jeong, J.H.; Yoon, W.L.; Jung, H.; Lee, H.T.; Lee, D.K.; Park, Y.K.; and Rhee, Y.W. 2004. Activity and characterization of the Co-promoted $\mathrm{CuO}-\mathrm{CeO}_{2} / \mathrm{Y}-\mathrm{Al}_{2} \mathrm{O}_{3}$ catalyst for the selective oxidation of $\mathrm{CO}$ in excess hydrogen. Appl. Catal. A: general 274: 25-32.

[123] Park, J.W.; Jeong, J. H.; Yoon, W.L.; and Rhee, Y.W. 2004. Selective oxidation of carbon monoxide in 